\title{
Invited review: Current state of genetic improvement in dairy sheep
}

\author{
A. Carta, ${ }^{1}$ Sara Casu, and S. Salaris
}

Research Unit-Genetics and Biotechnology, DIRPA-AGRIS Sardegna, 07040 Olmedo, Italy

\begin{abstract}
Dairy sheep have been farmed traditionally in the Mediterranean basin in southern Europe, central Europe, eastern Europe, and in Near East countries. Currently, dairy sheep farming systems vary from extensive to intensive according to the economic relevance of the production chain and the specific environment and breed. Modern breeding programs were conceived in the 1960s. The most efficient selection scheme for local dairy sheep breeds is based on pyramidal management of the population with the breeders of nucleus flocks at the top, where pedigree and official milk recording, artificial insemination controlled natural mating, and breeding value estimation are carried out to generate genetic progress. The genetic progress is then transferred to the commercial flocks through artificial insemination or natural-mating rams. Increasing milk yield is still the most profitable breeding objective for several breeds. Almost all milk is used for cheese production and, consequently, milk content traits are very important. Moreover, other traits are gaining interest for selection: machine milking ability and udder morphology, resistance to diseases (mastitis, internal parasites, scrapie), and traits related to the nutritional value of milk (fatty acid composition). Current breeding programs based on the traditional quantitative approach have achieved appreciable genetic gains for milk yield. In many cases, further selection goals such as milk composition, udder morphology, somatic cell count, and scrapie resistance have been implemented. However, the possibility of including other traits of selective interest is limited by high recording costs. Also, the organizational effort needed to apply the traditional quantitative approach limits the diffusion of current selection programs outside the European Mediterranean area. In this context, the application of selection schemes assisted by molecular information, to improve either traditional dairy traits or traits costly to record, seems to be attractive in dairy sheep. At the moment, the most effective strategy seems to be the strengthening of research projects aimed at find-
\end{abstract}

Received June 10, 2009.

Accepted August 11, 2009.

${ }^{1}$ Corresponding author: acarta@agrisricerca.it ing causal mutations along the genes affecting traits of economic importance. However, genome-wide selection seems to be unfeasible in most dairy sheep breeds.

Key words: dairy sheep, genetic improvement, geneassisted selection

\section{INTRODUCTION}

In this review, the evolution and the current state of genetic improvement in dairy sheep are illustrated according to the evolution of prevailing farming systems and production chains. Second, current breeding programs, mainly aimed at improving milk production traits, are described, focusing on the specific constraints of dairy sheep. A specific paragraph is dedicated to selection for scrapie resistance, which is currently strongly recommended by European health authorities. A further section presents changes in selection objectives caused by recent breeder interest in functional traits and consumer interest in healthy and functional foods. Finally, the potential applications of molecular genetics in the selection of dairy sheep are discussed.

\section{Farming Systems}

Worldwide production of sheep milk was $9,146,535 \mathrm{t} / \mathrm{yr}$ in 2007, a small amount compared with the 560,487,275 $\mathrm{t}$ of milk produced by dairy cattle (FAOSTAT, accessed April 27, 2009). Asia (50\%) and Europe (31\%) are the most important producers, whereas less is produced in Africa (19\%). About $46 \%$ of world sheep milk production originates in the Mediterranean basin. The most important countries in terms of number of sheep and production are Greece (750,000 $\mathrm{t}$ and 7,012,467 producing animals), Italy $(560,000 \mathrm{t}$ and $5,674,000$ producing animals), Spain (360,000 t and 2,400,000 producing animals), and France (254,000 t and 1,290,000 producing animals).

Dairy sheep have been farmed traditionally in the Mediterranean basin in southern Europe (France, Italy, Spain, Greece), in central Europe (Hungary and the Czech and Slovak Republics), in eastern Europe, and in Near East countries such as Turkey and Iran (De Rancourt et al., 2006; Zygoyiannis, 2006). Dairy sheep farming has commonly occupied less-favored areas, where ewes graze natural surfaces of low interest for 
grazing other species or for tillage and thus help to maintain the ecological equilibrium and the natural landscape. In addition, dairy sheep farming has contributed to sustaining economic activity and maintaining the population in rural areas. In several countries, milk is still produced for self-consumption with traditional farming techniques, mainly by low-productive, dualpurpose breeds. In these countries, ewes are still milked by hand and milk-fed lambs or young, fattened lambs are an important source of a farmer's income. In the past $50 \mathrm{yr}$, however, remarkable improvements in farming techniques have occurred in the Mediterranean European countries (Boyazoglu and Morand-Fehr, 2001). Many flocks have moved from marginal mountainous areas to low hills and lowlands, where higher production levels have been attained by using modern feeding practices and farm facilities such as milking machines. The productive cycle of Mediterranean sheep is very strictly linked to the Mediterranean climate, which is characterized by a mild winter, rainfalls occurring in autumn and spring, and a very dry summer. Such a climate affects the growth of herbage, which is usually available in autumn and mostly in spring. The typical dairy sheep productive cycle is characterized by one out-of-season lambing, which makes for optimal exploitation of the herbage growth cycle. Lambings occur in autumn when the grass starts to grow after the summer drought. Yearlings (on average 20-25\% of the total flock) usually lamb between January and March. The practice of 3 lambings in $2 \mathrm{yr}$ exists in some regions of Spain (Castilla-La Mancha and Castilla-Leòn) and in Israel (Ugarte et al., 2001; Galal et al., 2008), where lamb meat is an important contribution to the farmers' income. Generally, lambs are slaughtered or weaned after around $30 \mathrm{~d}$. After weaning, ewes are usually milked twice daily until late spring or early summer when they are simultaneously dried off because of summer drought. In these conditions, the flow of nutrients and energy from the pasture to the grazing sheep shows 2 critical constraints: a feed shortage in winter and a sharp decrease in herbage quality from spring to summer. Thus, although in most situations feeding is still based on grazing natural pastures, forage crops and supplementation with hay and concentrates have been increasing in importance in areas where irrigation is possible. However, TMR systems have been developed in only some Spanish regions where intensive production systems have been applied to crosses between local and improved breeds (Caja and de Rancourt, 2002). Simultaneously to the evolution of management techniques, production chains moved from home-made cheeses to industrial products following the large diffusion of modern cheese factories. In most European countries, dairy sheep industry is still based on local breeds that are well-adapted to their production areas, systems, and environments and that are often reared in specific, defined geographical areas, with high-quality cheese and meat products protected by quality labels.

Nowadays, dairy sheep farming systems vary from extensive (marked seasonal milk production, dual-purpose breeds, low feed supplementation, transhumance, handmilking, absence of farm facilities, farm-made cheese) to intensive (seasonal or continuous milk production, improved local breeds or crosses, exploitation of forage crops, high feed supplementation, milking machine and housing facilities, industrial cheeses) according to the economic relevance of the production chain and the specific environment and breed.

\section{Breeding Strategies}

The breeding strategy to improve dairy traits may involve either crossbreeding or purebreeding selection programs. Crossbreeding systems are often too complicated to manage in dairy production. Farmers rely only on the simplest scheme, which involves upgrading local populations to dairy-type breeds. Several comparisons between local and exotic breeds were done to determine whether local dairy breeds could be used successfully under the improved conditions or whether it would have been better to replace them with more productive genotypes (Ricordeau and Flamant, 1969; Zervas et al., 1975). The East Friesian, Awassi, and Chios breeds were once the most imported breeds (Barillet, 1997). However, poor adaptation in exotic purebred animals was observed (Galal, 1994; Sanna et al., 2001). This led to the use of crossbred animals, produced by first generation, or back-crosses, or both, with the local breed (Barillet et al., 2001a). The synthetic line Assaf in Israel was obtained from the local Awassi breed and the imported East Friesian breed (Epstein, 1985). The Assaf breed is still reared on some Israeli farms, although Awassi purebred ewes give similar or even better results (Pollott and Gootwine, 2004). Nevertheless, the practice of introducing high-performance foreign breeds still exists in intensive farming systems. Since 1980, in newly irrigated areas of Spain, the upgrading of native sheep populations has been obtained through the massive introduction of Awassi, Assaf, and Lacaune genetics. Nowadays, more than $45 \%$ of Spanish dairy sheep are foreign breeds and crossbreds (Ugarte et al., 2001). In recent years, there has been increasing interest in the Sarda breed from North African and East European countries where dairy sheep industry has been developing.

In most situations the chosen breeding strategy has been the genetic improvement of local breeds by modern selection schemes. Haenlein (2007) reported 
Table 1. Size of whole and recorded populations, milk yield and reference milking length, number of AI doses, number of progeny-tested rams by AI, and selection criteria according to different dairy sheep breeds (adapted from Astruc et al., 2008)

\begin{tabular}{|c|c|c|c|c|c|c|}
\hline Country & Breed & Population size & $\begin{array}{l}\text { Milk-recorded } \\
\text { ewes, n }\end{array}$ & $\begin{array}{l}\text { Milk yield, } \\
\text { L (reference } \\
\text { milking } \\
\text { length, d) }\end{array}$ & $\begin{array}{l}\text { AI doses, } \mathrm{n} \\
\text { (AI progeny- } \\
\text { tested rams, } \mathrm{n} \text { ) }\end{array}$ & Selection criteria ${ }^{1,2}$ \\
\hline \multirow{2}{*}{ France } & Manech RF & 282,000 & 72,861 & $177(149)$ & $57,400(135)$ & $\mathrm{FY}+\mathrm{PY}$ \\
\hline & Manech BF & 120,000 & 15,389 & $134(138)$ & $9,300(37)$ & $\mathrm{FY}+\mathrm{PY}$ \\
\hline Italy & Sarda & $2,975,000$ & 238,000 & $203(162)$ & $13,500(60)$ & $\mathrm{MY}+\mathrm{U}$ \\
\hline \multirow[t]{3}{*}{ Spain } & Latxa & 94,999 & 51,751 & $126(120)$ & $30,100(98)$ & MY \\
\hline & Manchega & 800,000 & 130,000 & $165(120)$ & $34,000(130)$ & MY \\
\hline & Churra & 700,000 & 39,283 & $89(120)$ & $15,250(52)$ & $\mathrm{MY}+\mathrm{P} \%$ \\
\hline
\end{tabular}

${ }^{1}$ Most breeding schemes include selection for scrapie resistance.

${ }^{2} \mathrm{MY}=$ milk yield, $\mathrm{FY}=$ fat yield, $\mathrm{PY}=$ protein yield, $\mathrm{F} \%=$ fat percentage, $\mathrm{P} \%=$ protein percentage, $\mathrm{U}=$ udder morphology.

wide differences in milk yield between recognized dairy sheep breeds, ranging from the lowest values of Corse (France) and Delle Langhe (Italy) breeds (108 and 115 $\mathrm{kg} /$ lactation, respectively) to the highest values of the East Friesian (Germany) and Awassi (Israel) breeds (632 and $495 \mathrm{~kg} /$ lactation, respectively), with high variability within breeds. However, comparison between breeds should be performed with caution because of a confounding effect between the genetic level of the breed and its management. For instance, the lactation length ranged from $120 \mathrm{~d}$ for Awassi in Turkey to 300 $\mathrm{d}$ for East Friesian in Germany. Even in the same country (France), milking length varies between 139 and $178 \mathrm{~d}$ for the Pyrenean and Corse breeds, respectively (Table 1). Fat percentage ranges from $5.86 \%$ in the Latxa breed to $7.49 \%$ in the Churra breed, whereas protein percentage ranges from $4.78 \%$ in the Red-Faced Manech breed to $6.11 \%$ in the Churra breed (Serrano et al., 1996; Legarra and Ugarte, 2001; Othmane et al., 2002; Barillet et al., 2008). Fat and protein percentages are 6.51 and $5.15 \%$, respectively, in the Lacaune breed (Barillet, 2007) and 6.50 and $5.76 \%$, respectively, in the Sarda breed (Carta et al., 2004).

Sheep breeding programs were developed in the 1960s. The most efficient selection scheme for local dairy sheep is based on pyramidal management of the population (Barillet, 1997) with the breeders of the nucleus flocks at the top, where pedigree and official milk recording, $\mathrm{AI}$, and controlled natural mating and breeding value estimation are carried out to generate genetic progress. The genetic progress is then transferred to the commercial flocks through AI or natural-mating rams. The lag between the nucleus flocks and the commercial population is proportional to the relative size of the recorded population and the flow of breeding animals. To balance economic and technical aspects of the selec- tion program, the optimal size of the nucleus should be in the range of 10 to $20 \%$ of the whole population (Elsen and Mocquot, 1974). This scheme has been primarily applied to the French Lacaune breed and has tripled the average milk yield from 1960 to 1990 in the nucleus flocks (Barillet et al., 2001a). Later, the Manech, Basc-Bérnaise, and Corse breeds in France, the Churra, Latxa, and Manchega breeds in Spain, and the Sarda breed in Italy implemented similar selection schemes.

\section{BREEDING PROGRAMS}

\section{Dairy Selection Objectives and Criteria}

Milk yield represents more than two-thirds of the total income of the dairy sheep industry. Thus, increasing milk yield is still the most profitable breeding objective for several breeds. Almost all of the milk is used for cheese production and, consequently, milk content traits are also important because they affect cheese yield and the typical taste of labeled cheeses. The negative genetic correlation between milk yield and content increases the need for introducing fat and protein percentages as selection objectives. Payment systems for sheep milk that are based on milk composition are applied in only some European countries (Pirisi et al., 2007), particularly where the sheep sector is well-developed. In many cases the economic weight of milk composition traits is not sufficient to refund farmers for the loss of genetic gain for milk yield. In any case, the introduction of milk composition traits as selection objectives should be realized only when a breeding program has reached asymptotic annual genetic gain for milk yield (Barillet, 1997). Thus, milk yield in milking period only is currently the selection criterion in most dairy sheep breeds 
Table 2. Range of genetic parameter estimates for milk traits on a lactation basis ${ }^{1}$

\begin{tabular}{|c|c|c|c|c|c|}
\hline Trait & Milk yield & Fat yield & Protein yield & Fat percentage & Protein percentage \\
\hline Fat yield & & 0.16 to 0.26 & 0.82 to 0.93 & 0.02 to 0.25 & -0.36 to -0.12 \\
\hline Protein yield & & & 0.18 to 0.27 & -0.18 to -0.28 & -0.01 to -0.15 \\
\hline Protein percentage & & & & & 0.31 to 0.69 \\
\hline
\end{tabular}

${ }^{1}$ Sanna et al., 1994; Carriedo et al., 1995; Barillet, 1997; Sanna et al., 1997b; El-Saied et al., 1999; Legarra and Ugarte, 2001; Othmane et al., 2002; Serrano et al., 2003; Barillet, 2007.

(Table 1). Only in the Lacaune (Barillet et al., 2001a) and French Pyrenean (Barillet et al., 2008) breeds did the selection criterion change to a linear combination of milk traits (fat and protein yields combined with fat and protein percentages). In Spain, protein percentage was added to milk yield as selection criterion only in the Churra breed (Gutierrez-Gil et al., 2009).

\section{Genetic Parameters of Milk Traits}

Genetic parameters on a total lactation basis for dairy traits are well known and follow the same patterns as in cattle (Table 2): heritabilities for milk, fat, and protein yields are moderate (around 0.30) and are lower than for fat and protein percentages (0.50-0.60). However, heritability of fat percentage is low in Spanish breeds probably because of the frequent problems in sampling individual milkings in dairy sheep. The genetic correlations between milk and fat and protein yields are positive and quite high (between 0.77 and 0.93). The genetic correlation estimates between milk yield and content are negative and show high variability. Correlations between fat and protein yields with the corresponding contents are also variable according to the breed.

\section{Use of $A I$}

Artificial insemination is the usual reproductive technique in dairy cattle whereas in dairy sheep its application is limited to breeding purposes. The infrequent use of AI in dairy sheep is mainly linked to the convoluted structure of the ewe cervix that makes precise deposition of semen difficult, thus reducing the chance of fertilization (Buckrell et al., 1994). Artificial insemination is mainly achieved with fresh semen after estrus synchronization through vaginal or cervical techniques. The average achieved fertility with fresh semen can be placed around $50 \%$ but with large variations between breeds (from $42 \%$ in the Sarda breed to $60-70 \%$ in the Lacaune and Manchega breeds; Sanna et al., 1997a; David et al., 2008). The use of frozen semen is limited because it has to be deposited directly in the uterus by surgical or laparoscopic techniques. The increase in pregnancy rates $(70-80 \%)$ is not sufficient to counterbalance the high costs associated with the difficulty of this technique. In these conditions, the diffusion rate of a ram is from 100 to 1,000 times lower than that of a bull. Ewes can be artificially inseminated only once during the reproduction season and the return is usually achieved by natural mating. Further difficulties in the application of this technique can arise from restrictions in the use of hormones, restrictions that aim to satisfy the demand of consumers for organic products. The spread of AI is also limited by the high management costs of AI centers that work only 1 to 2 mo during the reproductive season. The use of fresh semen makes it difficult to plan matings precisely and does not allow farmers to choose rams to mate with their elite ewes. Moreover, the farms involved should have good management skills to handle synchronized ewes. In these conditions, AI has to be managed in a collective form because it is a practice that positively influences the genetic improvement of the whole selected population and produces only a few direct advantages for the single farmer involved. This is particularly evident in situations where the breeding program is planned to perform AI on only a small portion of the whole flock. Therefore, in most breeds natural mating is still the main reproductive technique and AI is used within only the nucleus flocks with 3 main purposes: to create genetic links, to test young males, and to realize planned matings between elite rams and elite ewes. Moreover, semen of AI rams should be carefully shared among flocks with different environmental conditions to avoid the effects of genotype by environment interaction by assessing their average ability to produce in different environments (Sanna et al., 2002). This is particularly important in breeds with large variability of farming conditions. Barillet (1997) stated that potential genetic gain in the selection nucleus increases as the AI rate increases. In a simulation study, Smulders et al. (2007) showed that in the Manchega sheep breed the AI rate should be at least $50 \%$ to reach the maximum genetic progress. In some French breeds, AI is used as the main reproductive technique applied to a large part of the 
whole population either in the nucleus flocks or the commercial population to transfer the genetic gain created in the registered flocks (Barillet, 2007). In situations where the extensive use of AI is not feasible, the connectedness among contemporary groups is still a major problem for genetic evaluation. In these cases it is crucial to couple AI with controlled natural mating. For some breeds, farmers manage natural mating by grouping ewes with a single ram ("mating group") during the reproduction period. This management strategy makes it easy to determine the correct sire of a lamb based on the lambing date. Controlled natural mating is achieved with either young rams under progeny testing or adult proven rams. In most situations, there are only 1 or 2 natural mating sires per flock and year. Salaris et al. (2008) concluded that combining controlled natural mating with even small rates of planned AI generates several genetic links between flocks that are sufficient to permit accurate genetic evaluations not only of AI rams but also of natural-mating ones. An important role is carried out by AI-born rams used for controlled natural mating that produces additional indirect genetic links. As an example, in the Sarda breeding program $20 \%$ of primiparous ewes are born from AI and a further $30 \%$ come from natural matings realized by AI-born rams.

As a whole, current AI centers should accommodate large collective flocks where the best rams of the population are used either for AI or by farmers for controlled natural mating. This management strategy would allow either optimized use of AI or the distribution of controlled natural-mating rams.

In the few cases where the spread of AI is insufficient and the application of controlled natural mating is scarce, knowledge of pedigrees is quite poor and the effective size of the selected population is reduced so that it negatively affects the precision of genetic parameters and breeding value estimations. Currently, only selection schemes including AI (Table 1) show an appreciable annual genetic gain, although with different rates.

Modern assisted-reproductive technologies, such as multiple ovulation and embryo transfer, in vitro fertilization, and cloning, are not routinely applied in sheep breeding programs and are sporadically used for experimental purposes only.

\section{Milk Recording Programs}

In Mediterranean countries with the largest dairy sheep populations, the distribution of official milk recording varies widely: $20 \%$ of the whole population in France, $13 \%$ in Spain, $8 \%$ in Italy, and less than $1 \%$ in Greece (Astruc et al., 2008). Official milk recording in Italy, France, and Spain represents $90 \%$ of
International Committee for Animal Recording (ICAR) member countries (Table 1). In countries with smaller populations, milk recording concerns only a few private flocks.

In dairy sheep, costs of individual performance recording are high when compared with the economic value of an ewe. In many countries, these costs are largely covered by local governments. Milk recording also requires efficient extension services covering most farms, a structure that cannot be created quickly and cheaply. A simplification of milk recording is recommended because fixed costs are too high using the standard A4 testing, which consists of supervised monthly recording of 2 daily milkings. Consequently, simplified methods are suitable for achieving a large enough number of recorded animals to ensure a genetic gain for the whole population (Maria and Gabina, 1992). Two simplified methods, based on recording only 1 of the 2 daily milkings, were approved by ICAR (1992) regulations. They are 1) the classical AT (alternative milking) method and 2) the $\mathrm{AC}$ (corrected milking) method, which consists of a monthly milking test corrected for the evening and morning differences by using the ratio between the total volumes of milk produced by the whole flock at the 2 milkings.

According to the 2008 ICAR sheep enquiry (http:// www.waap.it/sheep_enquiry/), the simplified AT and $\mathrm{AC}$ methods are the most used, although some countries still apply A4. Only in France is an extremely simplified D method (i.e., nonofficial milk recording) applied to help commercial farmers optimize culling and replacement choices (Astruc et al., 2008). Conversely to dairy cattle, recording of milk composition traits is optional in sheep, as established in the ICAR (2007) guidelines. The collection of a milk sample for fat and protein content recording is still manual and thus time consuming and costly. Furthermore, it may represent more than $10 \%$ of the daily released milk. Therefore, the cost-effectiveness of milk composition recording is based upon the implementation of simplified designs. Currently, qualitative recording concerns only some breeds (Astruc et al., 2008). It is often designed with 1 sample per test-day (according to the AC or AT method used for milk yield) on only a part of the first or the first 2 lactations (Maria and Gabina, 1992; Sanna et al., 1997b; Rupp et al., 2003a). These simplified milk recording methods lead to less accurate information for genetic evaluations. The rate of milk content recording is high only in countries with a very small dairy sheep populations (37\% in Croatia, $53 \%$ in Slovak Republic, and $100 \%$ in Czech Republic, Germany, and Slovenia). In countries with large dairy sheep populations, the rate of recorded populations is $45 \%$ in Spain, $28 \%$ in France, and only $5 \%$ in Italy (Astruc et al., 2008). In 
this context, the use of milk meters may be a way to reduce recording costs. So far, most official milk recordings are still performed with jars, although 2 milk meters have recently been officially approved by ICAR for qualitative milk recording.

\section{Genetic Evaluation}

Although the test-day approach may theoretically be of use (Carta et al., 1995; El Saied et al., 1998; Serrano et al., 2001; Macciotta et al., 2005; Gutiérrez et al., 2007), the lactation approach is commonly used for the genetic evaluation of milk yield. Almost all breeds now use a repeatability BLUP-animal model, which includes fixed environmental effects and random additive genetic and permanent environment effects (Astruc et al., 1995).

According to ICAR (2007) guidelines, lactation yield is computed considering only the milk yield in the milking period in most breeds. These lactation yields are derived from elementary test-day information combined with Fleischmann's rules (ICAR, 1992). In some breeding systems (Israel or Germany), the lambs are removed from the ewe very soon after lambing so that the whole lactation is exploited by milking.

In dairy sheep, the length of the milking period is an important systematic source of environmental variability of milk yield. As described before, lambings often occur once per year, mainly in autumn for mature ewes and around 3 mo later for yearlings. In most situations, milking is prolonged in summer according to herbage availability of farms and dry-off is almost simultaneous for primiparous and mature ewes of a flock. This management strategy produces the statistical confounding of milking length with parity effects. Moreover, positive phenotypic and genetic correlations were found between milking length and milk yield (Barillet and Boichard, 1987; Sanna et al., 1994). For these reasons, including milking length in the model may produce inaccurate estimates of fixed effects and cause an inappropriate reduction of the genetic variability. Consequently, lactation milk yields are often preadjusted for milking length before genetic evaluation (Barillet et al., 1992; Portolano et al., 2006). A method to estimate multiplicative adjustments for milking length of completed lactation records was set up by Carta et al. (1998a). Moreover, in some breeds, in order to anticipate the genetic evaluation before the mating season, in-progress lactations are extended using a method based on the partial daily production for both milk yield and milk composition (Astruc et al., 1995).

The other important source of environmental variation in dairy sheep, mainly in farming systems with large variability in management techniques and en- vironmental conditions, is the flock-year effect. The flock-year effect is often considered in interaction with the age class or parity effects. The correct definition of the flock-year-age class or flock-year-parity factor is crucial to producing accurate EBV because its levels define the contemporary groups where daughters of AI or natural-mating rams or both are compared. Carta et al. (1998b) estimated preadjustment factors of lactation records to mature ewe equivalent (MEE) for the interaction age class-month of lambing in the Sarda breed. The use of MEE allows the inclusion of ewes born in different mating years in the same contemporary group and consequently increases the number of compared rams within a flock-year. This strategy is particularly important in situations with low rates of AI where only 1 or 2 rams per yr are used for natural mating. Legarra et al. (2005) proposed a Bayesian method to compare models differing in the definition of the contemporary group in Latxa dairy sheep.

The month of lambing is another important source of variation. Its magnitude can be noticeable in farming systems that are based on grazing because of the strong relationship between milk yield and the seasonal and annual variations of herbage availability. The interval between lambing and the first test-day with the usual methods of lactation computation may also have a noticeable effect, mainly in short lactations. An adjustment associated with the DIM of the first test-day is considered for some breeds. The effect of the number of suckled lambs is evident only in breeds of low production level. In high-producing breeds, a positive effect exists only on first test-day records of 2-lamb ewes.

As far as milk composition is concerned, fat and protein percentages are adjusted for the average lactation stage at the time of milk quality recording in French breeds. Lactation records are analyzed with a univariate animal model with repeated records similar to that used for the genetic evaluation of milk yield (Astruc et al., 2002).

\section{Realized Genetic Gains}

Most breeds show an increasing trend of milk production as a result of the development of management techniques. However, in semiextensive systems where grazing represents an important portion of feeding, this trend is lower and irregular because of annual variations of herbage availability to which these systems are very sensitive (Barillet et al., 2001a). The realized genetic gains are highly variable according to the different levels of management of the main selection tools. In this sense, the starting year of the program, AI rate, average pregnancy rate, and accuracy of milk recording and genetic evaluation play a crucial role. 


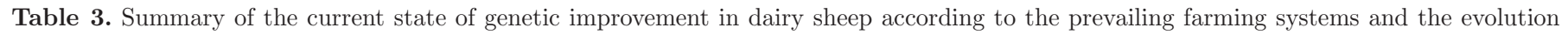
of the production chain

\begin{tabular}{|c|c|}
\hline Breeding system & Country (region) \\
\hline $\begin{array}{l}\text { Improved or upgraded (crossbreeding) local breeds; intensive systems; effective selection } \\
\text { schemes; industrial PDO }{ }^{1} \text { cheeses; national market and export }\end{array}$ & France (Roquefort), Spain (Castilla y Leon) \\
\hline $\begin{array}{l}\text { Large- to medium-size local breeds; semiintensive systems; effective selection schemes; } \\
\text { industrial PDO cheeses; national market and export }\end{array}$ & $\begin{array}{l}\text { Italy (Sardinia, Tuscany, Latium), France } \\
\text { (Pyrenees), Spain (Castilla La Mancha) }\end{array}$ \\
\hline $\begin{array}{l}\text { Large- to medium-size local breeds; semiextensive systems; feasibility of selection schemes; } \\
\text { farm-made and industrial cheeses; national or local scale markets }\end{array}$ & $\begin{array}{l}\text { Spain (Pays Vasco y Navarra), Italy (Sicily), } \\
\text { France (Corse), Greece, and Portugal }\end{array}$ \\
\hline $\begin{array}{l}\text { Nonimproved local breeds or crosses; traditional farming systems; no selection schemes; } \\
\text { farm-made cheeses for familiar and local consumption }\end{array}$ & $\begin{array}{l}\text { East Europe, Balkans, some local situations } \\
\text { in western Europe, and North Africa }\end{array}$ \\
\hline
\end{tabular}

${ }^{1}$ Protected Denomination of Origin.

In the Lacaune breed, the genetic gain for milk yield was close to $6 \mathrm{~L} / \mathrm{yr}$ between 1980 and 1994 (i.e., about $2.4 \%$ of the nucleus-average production, or 0.19 genetic $\mathrm{SD})$. Despite the genetic gains obtained for fat and protein percentages since $1987(+0.21$ and $+0.14 \% / y r$, respectively), the genetic gain for milk yield remained at $5 \mathrm{~L} / \mathrm{yr}$ until 2002. This breeding program benefits from a well-organized extension service and from high management level of farms, which makes it feasible to have accurate milk recording and high AI rates. The Corse breed, whose selection scheme was implemented in the 1990s, has achieved a genetic gain of $0.81 \mathrm{~L} / \mathrm{yr}$ (Astruc et al., 2002). The Red-Faced Manech, Blackfaced Manech, and Basco-Béarnaise Pyrenean breeds attained yearly genetic gains of $4.33,3.19$, and $3.53 \mathrm{~L}$, respectively (Astruc et al., 2002).

In Spain, the annual genetic improvement of the Churra breed was around 1\% (Ugarte et al., 2001) of the average reference lactation whereas in the Latxa breed the estimated genetic gains were 2.97 and 2.95 $\mathrm{L} / \mathrm{yr}$ for Black-Faced and Blond-Faced, respectively (Legarra et al., 2003). The realized genetic trend in the Manchega breed $(0.818 \pm 0.057 \mathrm{~L} / \mathrm{yr}, 0.84 \%$ of average reference lactation) was lower than those estimated in other Spanish breeds (Jurado et al., 2006). In Italy, the Sarda breed selection scheme was implemented in the early 1960s. The large application of milk recording and controlled natural mating allowed a moderate genetic gain of $0.5 \mathrm{~L} / \mathrm{yr}$ until the end of the 1980s. The introduction of AI, even at a low rate, combined with an efficient genetic evaluation resulted in a genetic gain of $2.0 \mathrm{~L} / \mathrm{yr}$ (Carta et al., 2004).

Finally, Table 3 illustrates the current state of genetic improvement in dairy sheep according to the prevailing farming systems and the evolution of the production chain. Note that this picture is quite arbitrary and should be continuously updated.

\section{Selection for Scrapie Resistance}

Scrapie is a transmissible spongiform encephalopathy (TSE) that affects sheep and goats. The identification of a variant of Creutzfeldt-Jakob disease in man, and the demonstration that the strain of prion protein isolated from this variant is indistinguishable from that causing bovine spongiform encephalopathy (BSE) in cattle (Bruce et al., 1997), led to increasing concern about the potential public health risks posed by TSE. Recent advances show that the pathological form of the protein may be found in the mammary gland of sheep under natural chronic inflammatory conditions (Ligios et al., 2005) and that classical scrapie can be transmitted from scrapie-affected ewes to transgenic mice via colostrum and milk (Lacroux et al., 2008) and to susceptible lambs by milk (Konold et al., 2008).

Resistance to scrapie in sheep is genetically determined by prion protein gene (PRNP) polymorphisms. Three are strongly linked to resistance or susceptibility: codons 136 (Ala, A, or Val, V), 154 (Arg, R, or His, $\mathrm{H}$ ), and 171 (Gln, Q, or R or H). Five combinations of these polymorphisms are the most frequent alleles: ARR, ARH, ARQ, AHQ, and VRQ (Belt et al., 1995). The ARR allele gives resistance whereas the other alleles are associated with different levels of susceptibility depending on the breed and the country (Elsen et al., 1999; Drögemüller et al., 2001).

Since their first discovery in 1998 (Benestad et al., 2003), an increasing number of scrapie cases with atypical characteristics have been diagnosed in sheep carrying the ARR allele. However, the European Food Safety Authority (EFSA, 2006) still recommends selection for the ARR allele given the low frequency of atypical scrapie within flocks and the level of susceptibility of the ARR allele. It also recommends a preservation of PRNP variability in order to face possible new type of TSE in sheep against which alleles others than ARR could provide a source of resistance. Moreover, Maestrale et al. (2005) suggested that the risk of scrapie in susceptible-genotype animals reduces as the withinflock frequency of resistant animals increases. This effect may allow the maintenance of a reservoir of susceptible alleles with a slightly increased risk of classical scrapie in susceptible animals.

Besides the major effect caused by the genotype at the PRNP locus, Moreno et al. (2008) found significant 
Table 4. Frequency of resistant allele of prion protein (PRNP) gene (ARR) in dairy sheep breeds before selection for scrapie resistance

\begin{tabular}{|c|c|c|c|c|c|}
\hline Country & Breed & Sample & Size & Initial ARR frequency & Reference \\
\hline \multirow{3}{*}{ France } & Manech Black-Faced & AI rams & 195 & 0.508 & Barillet et al. (2004) \\
\hline & Corse & AI rams & 100 & 0.505 & Barillet et al. (2004) \\
\hline & Manech Red-Faced & AI rams & 631 & 0.169 & Barillet et al. (2004) \\
\hline Italy & Sarda & Rams & 2,075 & 0.439 & Salaris et al. (2004) \\
\hline \multirow{2}{*}{ Spain } & Latxa Black-Faced & Rams & 1,804 & 0.243 & Legarra et al. (2004) \\
\hline & Churra & Ewes & 28,172 & 0.203 & Álvarez et al. (2006) \\
\hline
\end{tabular}

QTL on Ovis aries chromosomes (OAR) 6 and 18, affecting the incubation period observed in sheep that had the same PRNP genotype and were raised in the same environment. The European Commission adopted several decisions to protect human and sheep health from the risk of TSE. Particularly, the Commission Decision No. 100/2003 (European Commission, 2003) established that each member state must implement breeding programs to increase the resistance to TSE for each of its native sheep breeds or for breeds that formed a significant population in its territory.

Currently, most European breeds are involved in specific breeding programs. The goal is to increase the frequency of the ARR allele. There are large differences between breeding programs regarding the sizes of the whole and the selected populations, the preexistence of a selection scheme for production traits, and the initial frequencies of the resistant allele (Table 4). Of greatest importance is the size of the selected population that should be sufficient to provide resistant rams to the whole population. In any case, according to the initial $\mathrm{ARR}$ frequencies and the deadline for achieving the goal, specific strategies have to be adopted to avoid a decrease of the genetic merit for production traits and the decrease of genetic variability.

Since 2001, most European countries with a significant dairy sheep industry have established national breeding programs aimed at promoting scrapie resistance. To limit sampling and typing costs, only the breeding males are genotyped and, possibly, the elite young females that are expected to become dams of rams. In France, breeding programs for scrapie resistance officially started in 2001, although AI males had been genotyped since 1995 (Barillet, 2007). The initial ARR frequencies were different among French breeds (Table 4). The ARR frequency explained the higher prevalence of scrapie outbreaks in the Pyrénées Atlantiques department (Cazeau et al., 2008) where the Basco-Béarnaise, Manech Black-Faced, and Manech Red-Faced breeds are raised. From 2001 to 2005, the ARR frequency at the PRNP gene in the nucleus flocks increased from 0.59 to 0.78 (0.99 in AI rams) in the Lacaune breed and from 0.19 to 0.50 (0.74 in AI rams) in the Manech Red-Faced breed. In Italy, the scrapie plan officially started in 2004 for the Sarda breed, although AI rams have been genotyped since 2000 . The plan foresees the genotyping of breeding males and elite young females of the nucleus flocks, plus breeding males of flocks of high genetic merit that usually purchase rams from the nucleus flocks. In rams, the ARR frequency increased from 0.43 (birth year 2005) to 0.59 (birth year 2008). In the reproduction season of 2008, the ARR frequency in AI doses was 0.70. Other programs have been implemented in Spain and Greece but so far no published data are available about the evolution of PRNP gene allelic frequencies.

Selection of the PRNP gene can affect other traits of interest by different mechanisms (Elsen et al., 2006; Dawson et al., 2008). In fact, the PRNP gene may be directly involved with or closely linked to a gene affecting the genetic determinism of a trait. In the latter case, the potential effects depend on the linkage phase and may be positive (favorable alleles inherited with resistant PRNP alleles) or negative (unfavorable alleles inherited with resistant PRNP alleles). The linkage phase is expected to differ between populations or between families within population, according to the distance between the 2 genes, so that associations that are beneficial in one population (family) may be deleterious in another. Studies have been conducted in most European breeds to investigate potential effects of selection of the PRNP gene on a variety of dairy traits: milk yield and composition (Barillet et al., 2002; Marcotegui et al., 2003; Legarra et al., 2004; De Vries et al., 2005; Álvarez et al., 2006; Van Kaam et al., 2006; Salaris et al., 2007); SCC (De Vries et al., 2005; Álvarez et al., 2006) and udder morphology (Salaris et al., 2007); and reproductive and production traits (Ioannides et al., 2009). Consistently, no study found direct or closely linked gene effects on milk traits. Moreover, no QTL 
detection study showed the presence of genes affecting dairy traits on OAR 13 where the PRNP gene is located (Barillet et al., 2005; Elsen et al., 2006). On the contrary, 2 QTL were found on OAR 13 affecting SCC and nematode resistance (Rupp et al., 2003b; Moreno et al., 2006). The most probable locations of these QTL were rather far from the PRNP locus, suggesting that selecting for scrapie resistance should not change the allele frequency at a major gene for these traits.

Although direct effects on economically relevant traits have been excluded, selection for scrapie resistance may still affect the genetic merit of production traits. In small populations, the main risk is the potential random association between specific PRNP genotypes and the polygenic value for production traits. This risk should be carefully taken into account, mainly when the initial ARR frequency is low. In large selected populations, genetic gain on production traits may be limited by the loss of selection pressure caused by the introduction of an additional breeding goal. Only recently, Costard et al. (2009) proposed a deterministic model of simultaneous selection for a quantitative trait with underlying polygenic variation and a monogenic trait to optimize selection for scrapie resistance.

Salaris et al. (2007) showed that Sarda rams carrying $2 \mathrm{ARR}$ alleles had significantly lower daughter yield deviations for milk yield than those carrying 1 or no ARR alleles when no adjustment for the polygenic value of animals was performed. This difference is most likely a result of the selection strategy that uses homozygous ARR rams of low genetic merit and susceptible homozygous rams of only high genetic merit. To counterbalance this effect, homozygous ARR young rams without progeny test but with high pedigree value for milk yield have been certified as sires of sons. This strategy increases the availability of resistant rams with high genetic merit and shortens the generation interval on the sire-son pathway. On the other hand, to preserve favorable genes for production traits, susceptible rams of high genetic merit for milk yield have been used only for few planned matings with homozygous resistant elite ewes to produce young males for progeny test. Up until now, no selection scheme showed a marked decrease of genetic gains on production traits as a result of the introduction of selection for scrapie resistance. The other potential negative effect of increasing ARR allele frequency may be the loss of genetic variability. This effect is of great importance in populations that are small or are at risk of extinction. However, even in large populations selected for production traits, if the ARR allele frequency is low then this process should be monitored to avoid a reduction of exploitable genetic variance (Alfonso et al., 2006; Palhière et al., 2008).

\section{CHANGES IN SELECTION OBJECTIVES}

Dairy sheep production in Europe is changing dramatically with globalization, reduction in production subsidies, and increased emphasis on health, food safety, animal welfare, and the environment. In this context, several traits are becoming of interest for dairy sheep genetic selection: machine milking ability and udder morphology, resistance to diseases (mastitis, internal parasites, scrapie), milk nutritional value (fatty acid composition and bioactive peptides), safety of milk (presence of pathogens or contaminants such as antibiotics or hormones), adaptation to local breeding conditions (fitness, wool, longevity), feed efficiency (BW, feed intake, and body reserves), reproduction traits (sexual precocity, out-of-season lambing ability, female fertility), and lamb meat production (suckling ability, prolificacy).

The following sections will describe the current state and the perspectives of selection for some of these traits.

\section{Milking Ability and Udder Morphology}

Milking is the main labor cost in dairy sheep and influences milk production and udder health. The diffusion of milking machines and the need to contain time and costs of labor encourage breeders to look for animals that are able to rapidly release their milk without needing manual interventions (stripping) to complete the emptying of the udder. Selection for milking speed is limited by the difficulty of identifying a reliable selection criterion that is affordable to record on a large scale. The subjective score from 1 to 5 that is recorded directly by breeders in dairy cattle has not been realized in small ruminants because milking is a collective practice and flocks are large. Nevertheless, the genetic variability of milk emission traits in dairy ewes has been studied in experimental flocks (MarieEtancelin et al., 2006; Casu et al., 2007) by using an automatic milk-recording device, developed by INRASAGA (European patent no. 94916284.6). These studies showed that measures of the time needed to emit the first milk flow and the maximum milk flow had considerable individual variability. This fact suggests that they are genetically determined and can be improved through selection. Indeed, Marie-Etancelin et al. (2006) estimated high heritabilities of these traits $(0.55$ and 0.54 , respectively) in an experimental Lacaune flock. They also demonstrated that efficient selection on milk production over several decades results in an indirect genetic gain in milking speed because both maximum milk flow and time needed to emit the first milk flow 
Table 5. Range of heritabilities and genetic correlations between udder traits estimated in different dairy sheep breeds ${ }^{1}$

\begin{tabular}{lccccr}
\hline Trait $^{2}$ & UA & TP & UD & TD & DS $^{3}$ \\
\hline UA & \multirow{2}{*}{0.17 to 0.25} & 0.21 to 0.69 & 0.29 to 0.82 & 0.06 to -0.21 & 0.11 \\
TP & & 0.24 to 0.40 & -0.32 to -0.55 & 0.30 to 0.62 & 0.20 to 0.37 \\
UD & & 0.16 to 0.22 & 0.03 to 0.04 & -0.01 to 0.14 \\
TD & & & 0.18 to 0.40 & 0.21 to 0.26 \\
DS & & & & & \\
\hline
\end{tabular}

${ }^{1}$ Churra (Fernandez et al., 1997), Latxa (Legarra and Ugarte, 2005), Lacaune (Marie-Etancelin et al., 2005), and Sarda (Casu et al., 2006).

${ }^{2} \mathrm{UA}=$ udder attachment or degree of udder suspension, $\mathrm{TP}=$ teat position, $\mathrm{UD}=$ udder depth, $\mathrm{DS}=$ degree of separation of two halves, TD $=$ teat dimension.

${ }^{3}$ Scored only in Italy and France.

have a high favorable genetic correlation with milk yield. Moreover, the increasing diffusion of automatic detachment of clusters at a fixed time will strengthen the correlated genetic gain on milking speed when directly selecting only for milk yield. Moreover, milking speed is expected to increase because of the correlated response of this selection trait on milk yield recorded on milking machines equipped with time-dependent automatic cluster removers. The genetic progress expected from a direct selection on milk emission speed should be compared with the feasibility and costs of an accurate large-scale recording. Electronic meters approved by ICAR for recording milk emission flows have only very recently become available; their diffusion on a large scale seems unfeasible.

Genetic improvement in machine milkability may be achieved by selecting for udder morphology. More precisely, udders with low-implanted teats and low depth (i.e., close to the abdomen) are more easily and completely emptied by a milking machine (Labussière, 1988; Casu et al., 2000). An appraisal method for udder traits based on 9-point linear scales was first proposed for the Churra breed (de la Fuente et al., 1996) and has been adapted for other dairy sheep breeds (Fernandez et al., 1997; Serrano et al., 2002; Legarra and Ugarte, 2005; Marie-Etancelin et al., 2005; Casu et al., 2006). The main involved traits are teat placement, udder depth, udder cleft or degree of udder separation, and udder attachment or degree of udder suspension. In the Sarda breed, udder attachment is evaluated by a score of the ratio between the perimeter of udder insertion and the udder height rather than by a simple score of the perimeter of udder insertion as in Spanish breeds. The appraisal methods are reliable and objective because high repeatabilities of classifiers and high average correlations between different classifiers have been estimated (Marie-Etancelin et al., 2003; Casu et al., 2006). Repeatability estimates of linear udder traits were high within lactation and moderate to high between lactations (Fernandez et al., 1997; Marie-Etancelin et al.,
2003; Legarra and Ugarte, 2005; Casu et al., 2006). Heritability estimates ranged between 0.16 and 0.42 according to the scored trait and breed. Only for the Manchega breed did Serrano et al. (2002) report very low heritability estimates, especially for udder attachment (0.06). Finally, according to Legarra and Ugarte (2005), genetic correlations between traits scored in first and second lactations ranged between 0.85 and 0.95 . All these results showed that an accurate evaluation of udders is possible by using a single, early-lifetime score. The estimates of genetic correlations between udder conformation traits were generally moderate but favorable (Table 5), indicating that selection for one of them will positively influence overall udder conformation.

As far as the genetic correlations with milk yield are concerned, antagonistic correlations were estimated with udder depth: -0.36 in the Latxa breed, -0.37 in the Lacaune breed, -0.48 in the Sarda breed, and -0.82 in the Churra breed (Fernandez et al., 1997; Legarra and Ugarte, 2005; Marie-Etancelin et al., 2005; Casu et al., 2006; Barillet, 2007). Genetic correlations with teat placement ranged from 0 in the Lacaune breed to slightly negative (undesired) in other breeds $(-0.27$ and -0.15 in the Churra and Sarda breeds, respectively). Finally, estimated correlations with udder attachment were less consistent, being slightly negative $(-0.10)$ in the Sarda, null in the Churra, and positive (0.36) in the Latxa breeds. As previously mentioned, teat placement and udder depth have the strongest relationship with machine milkability, so selective breeding should focus on these traits. At present, the average teat placement values are not optimal for machine milking in most scored breeds, and udders tend to become deeper in the Lacaune and Sarda breeds (Marie-Etancelin et al., 2005; Casu et al., 2006). Teat placement can be directly improved, as it is moderately heritable and has a low genetic correlation with milk yield. Direct improvement of udder depth is difficult because of its high unfavorable genetic correlation with milk yield, which explains the negative genetic trends observed in the Lacaune 
and Sarda breeds. For the Sarda breed, Casu et al. (2006) suggested that genetic improvement of udder depth can be efficiently achieved by selecting for the ratio between the perimeter of udder insertion and udder depth, which has heritability similar to udder depth, a high favorable genetic correlation (0.82) with this trait, and a genetic correlation slightly unfavorable with milk yield. According to the 2008 ICAR yearly sheep milk enquiry (http://www.waap.it/sheep_enquiry/), udder morphology traits are recorded on farm in France for all dairy breeds, in Italy for the Sarda breed, in Spain for the Churra, Latxa, and Manchega breeds, and in Germany for the East Friesian breed. However, results of the genetic evaluations have been published only for the Lacaune and Sarda breeds (Marie-Etancelin et al., 2005; Casu et al., 2006). In both France and Italy, only primiparous ewes are scored for udder traits. The genetic evaluation is performed by using multiple-trait animal models that include (besides fixed effects such as the stage of lactation and the year-number of lambs interaction) the effect of flock-year classifier either as fixed (France) or random (Italy).

\section{Mastitis Resistance}

The annual incidence of clinical mastitis in small ruminants is generally lower than $5 \%$, but the prevalence of subclinical mastitis (resulting mainly from bacterial infections whose reservoir is generally in the udder or teat) ranges from 10 to $50 \%$ or more (Bergonier et al., 2003; Berthelot et al., 2006). Clinical mastitis is the primary health reason for involuntary culling in dairy ewes and causes additional economic losses from costs of veterinary treatments. Furthermore, efficient vaccination against the main pathogens is still lacking and the classical prophylactic measures can be too costly or tedious for small ruminant breeders. Over the past few decades, accumulating research has given strong evidence that the host's udder health is under genetic control in dairy ruminants (Mrode and Swanson, 1996; Rupp and Boichard, 2003). Most research is concerned with quantitative studies on milk SCC using a logarithmic transformation (SCS). Increase in milk SCC reflects the migration of neutrophils from the bloodstream to the udder to fight the infection. The SCC is therefore considered an indicator of udder health status. However, numerous factors influence SCC of infected and noninfected animals, such as the physiological status of the ewe, infection stage, and pathogens. Distributions of SCC in healthy, subclinically affected, and sick animals largely overlap. Preliminary results of an experiment based on 2 lines of Lacaune ewes divergently selected for SCC suggest that selection for reducing milk SCC leads to improved resistance to clinical and subclinical intramammary infections (Rupp et al., 2009). However, given the low frequency of clinical mastitis and probably the very low heritability, further investigations are needed to confirm this trend. Despite the lack of wellfocused experiments in dairy sheep, SCC is the criterion most used for evaluating dairy ewes' resistance to clinical and subclinical mastitis. Estimates of heritability of the lactation SCS for sheep ranged between 0.10 and 0.20 (El Saied et al., 1999; Mavrogenis et al., 1999; Barillet et al., 2001a; Othmane et al., 2002; Rupp et al., 2003a; Serrano et al., 2003; Legarra and Ugarte, 2005; Riggio et al., 2007; Sechi et al., 2007). Relationships between milk production and udder health traits are less consistent in sheep than in cows, with published genetic correlations between SCC and milk yield ranging from favorable (El Saied et al., 1999; Othmane et al., 2002; Legarra and Ugarte, 2005) to slightly antagonistic (Rupp et al., 2003a). The moderate genetic antagonism with milk yield estimated in the Lacaune breed (Rupp et al., 2003a) is in agreement with the dairy cattle literature (Rupp and Boichard, 2003) and was further confirmed by an experiment based on divergently selected lines for milk yield (Barillet et al., 2001b). As shown in cattle, both phenotypic and genetic relationships exist between udder morphology and udder health. Sechi et al. (2007) showed that udder scoring performed in first lactation is a useful tool for detecting animals with a high risk of mammary inflammatory status or showing high SCS during their productive lives. Genetic correlations between lactation SCS and udder traits as estimated in several breeds were moderately favorable and ranged from -0.10 to -0.32 (Legarra and Ugarte, 2005; MarieEtancelin et al., 2005; Barillet, 2007; Sechi et al., 2007). Thus, selection on udder morphology traits will lead to a favorable correlated genetic response on SCC.

Somatic cell count recording has been implemented in several breeds (Astruc et al., 2008) in France (Lacaune and Pyrenean), Italy (Sarda), and Spain (Manchega, Churra, and Latxa). However, exhaustive monthly sampling, usually available in dairy cattle, is prohibitive in sheep. Thus, as for fat and protein contents, SCC recording concerns only part of the selected population (first or second lactation or both) with simplified schemes based on 2 to 4 test-days per lactation. So far only the Lacaune breed has included SCS as selection criterion in addition to production traits and udder morphology (Barillet, 2007). The model for the genetic evaluation is a repeatability animal model for the lactation-average SCS, including the fixed effects of flock-year-parity, age, and month at calving within parity and year (Rupp et al., 2002). 


\section{Nematode Resistance}

In Europe, nematode infections are the most costly endemic disease in meat production systems and are nearly as costly as mastitis in milk production systems. Previous studies in small dairy ruminants showed that gastrointestinal strongyle infections reduce the availability of nutrients for milk production (Jordan and Pérez, 1991; Hoste and Chartier, 1993). The favorable effect of anthelmintic treatments on increasing milk production in dairy or lactating ewes (Fthenekis et al., 2005; Cringoli et al., 2008; Scala et al., 2008) has been demonstrated. However, the development of strains of gastrointestinal strongyles resistant to anthelmintics is a widespread phenomenon that is becoming prevalent in Europe (Kaplan, 2004; Papadopoulos, 2008). Selecting for the ability of the individual host to resist infection or control the parasite lifecycle would be more effective than selecting for tolerant animals. Genetically improving nematode resistance could decrease anthelmintic requirements, reduce pasture contamination leading to decreased larval challenge, or both, and hence indirectly benefit health and performance (Bishop and Stear, 2003; Eady et al., 2003).

Evidence of across- and between-breed variability in nematode parasite resistance has been accumulated. Fecal egg count (FEC) is the most widely used criterion to quantify nematode resistance. Heritability of FEC, after appropriate logarithmic transformation, is moderate in lambs (Woolaston and Piper, 1996; Morris et al., 1997; Woolaston and Windon, 2001; Bishop et al., 2004; Gruner et al., 2004a,b) and in periparturient ewes (Woolaston, 1992; Morris et al., 1998; Bishop and Stear, 2001). Resistances to different species of nematodes tend to be interrelated, with genetic correlations between the FEC values arising from different species or genera of parasites generally being close to 0.5 (Bishop et al., 2004) or higher in some cases (Gruner et al., 2004a). Selection criteria other than FEC have also been proposed. Among those, average worm size and the number of eggs in utero of adult worms or antibodies response are included (Stear et al., 1997; Davies et al., 2005). The latter demonstrated moderate to high heritabilities and was favorably genetically correlated with both FEC and worm fecundity (Davies et al., 2005; Bishop and Morris, 2007).

Sheep selected on the basis of their response to artificial challenges respond similarly when exposed to natural infection (Woolaston et al., 1990), and high positive genetic correlation was estimated between FEC recorded under artificial or natural infection (Gruner et al., 2004b). These results demonstrated that selecting for resistance to artificial challenge would be effective in improving resistance to natural gastrointestinal in- fections. This is very important from a logistic point of view, considering the costs and laboriousness of data recording under field conditions. Even for dairy sheep, the genetic capability for nematode resistance may thus be predicted by administering a performance test to AI-center rams that were previously artificially challenged. Implementation of nematode resistance in breeding programs requires knowledge of the relationships with other traits of selective interest. Afolayan et al. (2009) estimated a correlation of low or no significance between milk yield and FEC in crossbred ewes. Sechi et al. (2009) estimated a genetic correlation of $0.21 \pm 0.16$ between FEC and the lactation SCS in an experimental population of back-cross Sarda $\times$ Lacaune ewes. Despite the large standard error, this genetic correlation estimate shows that selection for 1 of the 2 traits would have no detrimental effect on the other. Further analyses on more structured populations will be useful to more accurately analyze the genetic relationships between these 2 traits. So far no selection program for improving nematode resistance has been implemented in dairy sheep.

\section{Fatty Acid Composition}

The fatty acid (FA) content and profile of milk fat affects the technological properties and the nutritional value of dairy products. Sheep cheese is highly appreciated for its taste and flavor but is commonly considered potentially negative for human health because of its high fat content. As a whole, the overall FA profile should be considered for its effects on human health. Data from sheep milk show that the saturated FA level in milk fat is quite high (more than 60\%) whereas monounsaturated FA and polyunsaturated FA levels are approximately 28 and $6 \%$, respectively (Cabiddu et al., 2005). A more favorable FA profile for human health would present less saturated FA and more monounsaturated and polyunsaturated FA, although not all of the FA of a specific class have the same effect on human health (Hayes and Khosla, 1992; Pascal, 1996). In this context, to satisfy new consumer demands, it is of interest to modify the FA composition of sheep milk to improve the dietetic and nutritional value of sheep cheese without negatively affecting the typical taste and flavor of products. Recently, the main interest has been on conjugated linoleic acid (CLA) content because of its various beneficial effects on human health (Bhattacharya et al., 2006). The generic name CLA is a collective term embracing all octadecadienoic acids (C18:2) with a conjugated double-bond system. Luna et al. (2005) showed that most of the CLA in ewe's milk corresponds to cis-9, trans-11 (rumenic acid has been proposed as the common name for this specific CLA 
isomer by Kramer et al., 1998), which represented more than $75 \%$ of total CLA. A portion of CLA is formed in the rumen by biohydrogenation of linoleic acid, escapes further biohydrogenation, and is absorbed in the digestive tract (Griinari and Bauman, 1999). The extent of this process is minimal, whereas the intermediate product of CLA biohydrogenation [trans 11-C18:1; vaccenic acid (VA)] accumulates (Harfoot and Hazlewood, 1997). The other important source of VA in the rumen is the biohydrogenation of the linolenic acid (C18:3). This pathway does not have CLA as an intermediate. The VA produced in the rumen is desaturated to produce CLA in the mammary gland tissues by stearoylCoA desaturase (SCD). Stearoyl-CoA desaturase can use different FA as substrate and influences the amount of several unsaturated FA. On the whole, there is evidence that milk CLA basically comes from mammary synthesis by the action of SCD on VA provided by the rumen (Bauman et al., 2006).

Several studies show large variations in the CLA content of milk fat and highlight the importance of nutrition in modifying the FA profile either in cattle or sheep and goats (Demeyer and Doreau, 1999; Chilliard et al., 2000). Moreover, many reports are available on the effects of different pastures on the FA profile of sheep milk (Cabiddu et al., 2005; Addis et al., 2006). In contrast, far fewer studies are available on the genetic determinism of these traits (Soyeurt et al., 2007; Mele et al., 2009). This is mainly because of the fact that large-scale phenotyping is needed to produce accurate genetic studies and, until recently, the only available technique has been the very time-consuming and costly gas chromatography technique. However, Soyeurt et al. (2006b) showed that genetic variation exists across and within cattle breeds for the FA profile of milk, using a mid-infrared spectrometry technique that was less laborious and expensive (Soyeurt et al., 2006a). Carta et al. (2008) estimated repeatabilities and sire variance components for the 17 most abundant FA and their sums and ratios in a back-cross Sarda $\times$ Lacaune population created in the framework of a QTL detection experimental design (Barillet et al., 2005). The FA content was determined by gas chromatography on individual milk samples taken twice during the morning milking in the middle of the second and third lactations. The overall pattern of raw correlations showed that the FA profile is a very complex system resulting from numerous interrelationships between basic FA. These results suggest that strategies for improving FA composition have to take into account that variation in one basic FA implies correlated variations in other variables, so that the overall FA profile can be affected. As far as repeatability estimates are concerned, all the analyzed variables showed important individual vari- ability (14.1-57.3\%). Sire variances ranged from 3 to $23 \%$. In particular, repeatability estimates of CLA and the ratio between CLA and VA were 29.7 and 34.6\%, respectively. The corresponding sire variance components were 8.3 and $5.6 \%$. These results suggest that a certain amount of additive genetic variance is available for selection through the classical quantitative approach for most FA. However, this approach requires large-scale phenotyping in the nucleus flocks at reasonable costs. At the moment, the costs of milk sampling and gas chromatography analyses are high. However, a mid-infrared technique used for the determination of FA content in cow milk (Soyeurt et al., 2006a) may be a promising strategy in dairy sheep as well.

\section{Other Traits}

Female fertility should be monitored in sheep breeds where selection focuses on milk yield because there is evidence that increased milk production results in reduced female fertility in dairy cattle. This is likely a result of a more negative energy balance (Veerkamp et al., 2003). In dairy cattle, antagonistic genetic correlations between female fertility and milk production were estimated (Wall et al., 2003; Gonzalez-Recio et al., 2006). In dairy sheep, however, matings generally occur 5 to 6 mo after the lactation peak and no evidence of a reduction of female fertility as a result of selection on milk yield has been reported until now. David et al. (2008) reported low heritability estimates of female fertility after AI in both young and adult ewes (0.04 and 0.05 , respectively). The genetic correlation between milk yield and lamb AI fertility was not significant whereas the genetic correlation between milk yield and AI fertility in adult ewes $(-0.23)$ was in the range of antagonistic correlations reported in dairy cattle. Consequently, these results showed that selection for milk yield can induce an indirect decrease in AI fertility. Nevertheless, no phenotypic decrease in fertility of AI matings has been observed in the Lacaune breed.

The ability to breed out of season is a desirable characteristic; the sooner ovarian activity starts in early spring, the earlier the ewe will get pregnant, lamb, and start lactation. Genetic control of seasonality between and within breeds has been clearly demonstrated (Hanocq et al., 1999; de Heredia et al., 2002; Avdi et al., 2003). Heritability of spontaneous ovulatory activity in early spring ranged between 0.10 (de Heredia et al., 2002) and 0.20 (Hanocq et al., 1999). This trait should be of interest in controlling the onset of the breeding season, especially if hormonal treatments (often used to induce estrus cycles) would be forbidden. Another trait of potential interest is heat stress because of its effect on performance traits, especially in Mediterranean ar- 
eas that are characterized by exposure to considerable heat from between 3 and 6 mo annually (Finocchiaro et al., 2005).

\section{POTENTIAL APPLICATIONS OF MOLECULAR GENETICS}

Milk protein polymorphisms have been regarded as potential tools for the selection of dairy ruminants. So far in dairy sheep, research on this topic is limited to $\alpha_{S 1}$-casein and $\beta$-LG loci. For $\alpha_{S_{1}}$-casein, only the Welsh variant, also named the $\mathrm{D}$ variant, has been related to the diminution of casein content and renneting properties (Pirisi et al., 1999). Nevertheless, in investigated breeds, its allelic frequency is so low that its potential use for dairy sheep selection is minimal. On the other hand, the relationship between $\beta-L G$ polymorphism and dairy traits or technological properties of milk are too inconsistent to consider this polymorphism as a potential breeding tool (Barillet et al., 2005). Thus, in current breeding programs molecular information is used for selection for scrapie resistance and parentage testing by using microsatellite markers. Parentage testing is essentially used for breeding males only in breeds where natural mating is still the main reproduction technique. In these populations, there is an increasing interest for breeders to move from simple parentage testing to paternity assignment for both breeding males and females. This application can avoid the laborious practice of controlled natural mating, allowing multiple-sire mating groups. Through this tool, even large flocks in which the management of several mating groups is difficult can participate in breeding programs. Typing costs have been too high so far, although a clear decreasing trend is occurring. In the Sarda breed, with the aim of reducing sampling and typing costs, a system is being set up based on DNA extracted from the same milk sample used for the milk quality recording and the analysis of few multiplexes, including very informative microsatellite markers.

Selection based on the traditional quantitative approach has obtained appreciable results in Mediterranean countries, mainly in terms of milk yield. On the other hand, many traits of new interest have low heritabilities and high recording costs. Even fat and protein contents are recorded in dairy sheep at high costs and with simplified recording procedures that may compromise the genetic response. For low-heritable traits, the results in terms of genetic gain of the traditional approach are often not sufficient to justify the cost. For traits costly to record, even if genetic gain was high, phenotype recording costs could be so large that they may counterbalance the income from the genetic progress. Furthermore, in the case of multitrait selection, the genetic relationships existing between the involved traits must be taken into account. In fact, when a negative genetic correlation exists, as for milk yield and fat and protein contents, the selection criterion must be a compromise that will lead to a reduction of the genetic gain of each trait. Thus, for milk composition traits, it is of interest to select for specific genes with a nonpleiotropic effect on milk yield.

In these conditions, the potential advantage of applying gene-assisted selection (Dekkers, 2004), either to speed selection of routinely measured traits or to implement selection for traits costly to record, seems to be attractive in dairy sheep. Since its inception in 1995 (Crawford et al., 1995), the sheep linkage map has been regularly updated (Maddox and Cockett, 2007) with the most recent version (4.7) released in December 2006 (http://rubens.its.unimelb.edu.au/ jillm/jill. htm). The sex-averaged sheep linkage map has essentially complete coverage of the sheep genome. It spans approximately 3,570 $\mathrm{cM}$ and is comprised of 1,430 markers representing 1,371 loci. The most common markers currently on the map are microsatellites. On this basis, several regional projects started at the end of the 1990s in the European Union to dissect the genetic variability of economically relevant traits. A research project funded by the European Commission (QLK5CT-2000-00656; "genesheepsafety") was initiated to detect QTL for production and functional traits in sheep. In dairy sheep, 2 pure breeds (Lacaune in France and Churra in Spain) and 1 experimental back-cross Sarda $\times$ Lacaune population in Italy were involved. Using low-density microsatellite maps (between 130 and 167 markers spread over the 26 sheep autosomes), these experiments allowed identification of several QTL affecting functional and productive traits (e.g., milk traits, SCC, nematode resistance, FA contents in milk fat, and udder traits). Main results are summarized in Table 6 .

Most of the QTL found are population-specific and show low significance levels and large confidence intervals and, because of this, their use in selection programs is still unfeasible. Therefore, starting from these results, fine-mapping studies are underway in several countries. Up until now, only 2 positional candidate genes showed polymorphisms associated with traits of economic interest: acyl CoA:diacylglycerol acyltransferase 1 (DGAT1) for fat and protein content (Scatà et al., 2009) and SCD for CLA content in milk fat (Miari et al., 2009). Other candidate genes that encode enzymes that are directly involved in FA metabolism are now under study. Moreover, it is expected that new candidate genes will be identified by microarray analysis on total mRNA of the mammary gland (Moioli et al., 2007).

The recent advent of affordable high-throughput technology for SNP, together with a reduction in se- 
Table 6. Quantitative trait loci detected in the framework of the European research project QLK5-CT-2000-00656 (genesheepsafety)

\begin{tabular}{|c|c|c|c|}
\hline Trait & Resource population $^{1}$ & Ovine chromosome & Reference \\
\hline Protein yield & $\mathrm{S} \times \mathrm{L}$ & $3,16,20$ & Carta et al. (2002) \\
\hline Fat yield & $\mathrm{S} \times \mathrm{L}$ & $3,16,20$ & Carta et al. (2002) \\
\hline \multirow[t]{2}{*}{ Protein content } & $\mathrm{S} \times \mathrm{L}$ & 1 & Carta et al. (2002) \\
\hline & Churra & 3 & Gutiérrez-Gil et al. (2009) \\
\hline \multirow{2}{*}{ Fat content } & Churra & 9 & El Zarei et al. (2002) \\
\hline & Lacaune & 9 & Barillet et al. (2005) \\
\hline Fecal egg count & $\mathrm{S} \times \mathrm{L}$ & Various chromosomes & Moreno et al. (2006) \\
\hline \multirow[t]{3}{*}{ SCC } & $\mathrm{S} \times \mathrm{L}$ & $6,13,18,19$ & Rupp et al. (2003b) \\
\hline & Churra & 20 & Gutiérrez-Gil et al. (2007) \\
\hline & Lacaune & $6,12,16$ & Rupp et al. (2003b) \\
\hline Udder depth & Churra & 14,20 & Gutiérrez-Gil et al. (2008) \\
\hline \multirow[t]{2}{*}{ Teat placement } & $\mathrm{S} \times \mathrm{L}$ & 9,14 & Casu et al. (2003) \\
\hline & Churra & 7,26 & Gutiérrez-Gil et al. (2008) \\
\hline
\end{tabular}

${ }^{1} \mathrm{~S} \times \mathrm{L}=$ Sarda $\times$ Lacaune back-cross population.

quencing costs, is resulting in a shift to SNP markers for trait mapping and association studies in sheep. Indeed, since January 2009, a high-density SNP array (the Illumina Ovine SNP50 BeadChip, Illumina Inc., San Diego, CA) has been commercially available. These genomic resources have been driven by the unique collaborative efforts of the International Sheep Genome Consortium (ISGC), an open-membership research group led, principally, by academic and industry groups in New Zealand and Australia, but also involving active participation and funding contributions from the European Union and the United States. This technology is expected to increase the effectiveness of current fine-mapping studies. In fact, many research groups involved in previous QTL detection projects are now planning to use high-density SNP arrays to refine their results. Compared with dairy cattle, at the moment, genome-wide selection (Meuwissen et al., 2001) seems to be impractical. The main reasons are the high costs of high-density SNP arrays and the difficulty in finding well-structured reference populations to estimate SNP effects for traits that are routinely measured or costly to record.

\section{CONCLUSIONS}

The breeding programs currently ongoing in dairy sheep that are based on the traditional quantitative approach have achieved appreciable genetic gains for milk yield. In some cases, selection goals such as milk composition, udder morphology, and SCC have been implemented. Most of them have also been involved in selection for scrapie resistance based on molecular information. However, the possibility of including other traits of selective interest is limited by high recording costs. Moreover, the high organizational effort needed to apply the traditional quantitative approach limits the diffusion of current selection programs outside the Mediterranean area. In this context, the application of selection schemes assisted by molecular information, to improve either traditional dairy traits or traits that are costly to record, seems to be attractive in dairy sheep. At the moment, the most effective strategy seems to be increasing research efforts to find causal mutations along genes affecting traits of economic importance. This approach will take advantage of preexisting experimental populations that were created for QTL detection purposes and the availability of high-density SNP arrays. Nevertheless, genome-wide selection seems to be unachievable in most dairy sheep breeds. The main reasons include the high cost of high-density SNP arrays and the difficulty in finding well-structured reference populations to estimate SNP effects for traits that are routinely measured or costly to record.

\section{ACKNOWLEDGMENTS}

This work was realized in the framework of the research program "APQ per la ricerca scientifica e 
l'innovazione tecnologica-Progetto P5a-Attivazione del Centro di biodiversità animale per la valorizzazione del patrimonio animale con riferimento alla produzione e alla ricerca al servizio dell'allevamento" of the Regional Government of Sardinia (Italy).

\section{REFERENCES}

Addis, M., A. Cabiddu, G. Pinna, M. Decandia, G. Piredda, A. Pirisi, and G. Molle. 2006. Milk and cheese fatty acid composition in sheep fed Mediterranean forages with reference to conjugated linoleic acid cis-9, trans-11. J. Dairy Sci. 88:3443-3454.

Afolayan, R. A., N. M. Fogarty, J. E. Morgan, G. M. Gaunt, L. J. Cummins, and A. R. Gilmour. 2009. Preliminary genetic correlations of milk production and milk composition with reproduction, growth, wool traits and worm resistance in crossare ewes. Small Rumin. Res. 82:27-33.

Alfonso, L., A. Parada, A. Legarra, E. Ugarte, and A. Arana. 2006. The effects of selective breeding against scrapie susceptibility on the genetic variability of the Latxa Black-Faced sheep breed. Genet. Sel. Evol. 38:495-511.

Álvarez, L., B. Gutiérrez-Gil, F. San Primitivo, L. F. de la Fuente, and J. J. Arranz. 2006. Influence of prion protein genotypes on milk production traits in Spanish Churra sheep. J. Dairy Sci. 89:1784-1791.

Astruc, J. M., F. Barillet, A. Barbat, V. Clément, and D. Boichard. 2002. Genetic evaluation of dairy sheep in France. 7th World Congr. Genet. Appl. Livest. Prod., Montpellier, France. Commun. No 01-45. INRA, Castanet-Tolosan, France.

Astruc, J. M., F. Barillet, A. Carta, M. Fioretti, E. Gootwine, D. Kompan, F. J. Romberg, and E. Ugarte. 2008. Report of the working group on milk recording of sheep. Pages 275-282 in Proc. 36th Biennial Session of the International Committee for Animal Recording (ICAR), Niagara Falls, NY. ICAR technical series no. 13. Identification, breeding, production, health and recording on farm animals. J. D. Slatter, ed. ICAR, Rome, Italy.

Astruc, J. M., F. Barillet, A. Carta, D. Gabina, E. Manfredi, B. Moioli, A. Piacère, A. M. Pilla, S. R. Sanna, J. P. Sigwald, and E. Ugarte. 1995. Use of the animal model for genetic evaluation of dairy sheep and goats in several ICAR member countries. Pages 271-275 in Proc. 29th Biennial Session of International Committee for Animal Recording (ICAR), Ottawa, Ontario, Canada. EAAP publication no. 75. Wageningen, Pers, Wageningen, the Netherlands.

Avdi, M., G. Banos, A. Kouttos, L. Bodin, and P. Chemineau. 2003. Sources of variation and genetic profile of spontaneous, out-of season ovulatory activity in the Chios sheep. Genet. Sel. Evol. 35:65-76.

Barillet, F. 1997. Genetics of milk production. Pages 523-564 in Genetics of Sheep. L. Piper and A. Ruvinsky, ed. CAB International Wallingford, UK.

Barillet, F. 2007. Genetic improvement for dairy production in sheep and goats. Small Rumin. Res. 70:60-75.

Barillet, F., O. Andreoletti, I. Palhière, X. Aguerre, J. M. Arranz, S. Minery, C. Soulas, J. P. Belloc, M. Briois, G. Frégeat, P. Teinturier, Y. Amigues, J. M. Astruc, M. Y. Boscher, and F. Schelcher. 2002. Breeding for scrapie resistance using PrP genotyping in the French dairy sheep breeds. Pages 683-686 in Proc. 7th World Congr. Genet. Appl. Livest. Prod., Montpellier, France. INRA, CastanetTolosan, France.

Barillet, F., J. J. Arranz, and A. Carta. 2005. Mapping quantitative trait loci for milk production and genetic polymorphisms of milk proteins in dairy sheep. Genet. Sel. Evol. 37(Suppl. 1):109-123.

Barillet, F., J. M. Astruc, G. Lagriffoul, X. Aguerre, and B. Bonaïti. 2008. Selecting milk composition and mastitis resistance by using a part lactation sampling design in French Manech red faced dairy sheep breed. Pages 129-136 in Proc. 36th Biennial Session of the International Committee for Animal Recording (ICAR), Niagara Falls, NY. ICAR technical series no. 13. Identification, breeding, production, health and recording on farm animals. J. D. Slatter, ed. ICAR, Rome, Italy.
Barillet, F., and D. Boichard. 1987. Studies on dairy production of milking ewes. I. Estimates of genetic parameters for total milk composition and yield. Genet. Sel. Evol. 19:459-474.

Barillet, F., D. Boichard, A. Barbat, J. M. Astruc, and B. Bonaiti. 1992. Use of an animal model for genetic evaluation of the Lacaune dairy sheep. Livest. Prod. Sci. 31:287-299.

Barillet, F., C. Marie, M. Jacquin, G. Lagriffoul, and J. M. Astruc. 2001a. The French Lacaune dairy sheep breed: Use in France and abroad in the last 40 years. Livest. Prod. Sci. 71:17-29.

Barillet, F., I. Palhiere, J. M. Astruc, M. Brochard, M. Baelden, X. Aguerre, F. Fidelle, J. M. Arranz, J. P. Belloc, M. Briois, G. Fregeat, C. Soulas, O. Andreoletti, F. Corbiere, and F. Schelcher. 2004. Pages 87-100 in Le programme français d'éradication de la tremblante du cheptel ovin fondé sur l'utilisation de la génétique. INRA Prod. Anim., numéro hors série. INRA, Castanet-Tolosan, France.

Barillet, F., R. Rupp, S. Mignon-Grasteau, J. M. Astruc, and M. Jacquin. 2001b. Genetic analysis for mastitis resistance and milk somatic cell score in French Lacaune dairy sheep. Genet. Sel. Evol. 33:397-415.

Bauman, D. E., I. H. Mather, R. J. Wall, and A. L. Lock. 2006. Major advances associated with the biosynthesis of milk. J. Dairy Sci. 89:1235-1243.

Belt, P. B., I. H. Muileman, B. E. C. Scrheuder, J. Bos-de Ruijter, A. L. J. Gielkens, and M. A. Smits. 1995. Identification of five allelic variants of the sheep PrP gene and their association with natural scrapie. J. Gen. Virol. 76:509-517.

Benestad, S. L., P. Sarradin, B. Thu, J. Schonheit, M. A. Tranulis, and B. Bratberg. 2003. Cases of scrapie with unusual features in Norway and designation of a new type, Nor98. Vet. Rec. 153:202208.

Bergonier, D., R. de Cremoux, R. Rupp, G. Lagriffoul, and X. Berthelot. 2003. Mastitis of dairy small ruminants. Vet. Res. 34:689-716.

Berthelot, X., G. Lagriffoul, D. Concordet, F. Barillet, and D. Bergonier. 2006. Physiological and pathological thresholds of somatic cell counts in ewe milk. Small Rumin. Res. 62:27-31.

Bhattacharya, A., J. Banu, M. Rahmana, J. Causey, and G. Fernandes. 2006. Biological effects of conjugated linoleic acids in health and disease. J. Nutr. Biochem. 17:789-810.

Bishop, S. C., F. Jackson, R. L. Coop, and M. J. Stear. 2004. Genetic parameters for resistance to nematode infections in Texel lambs. Anim. Sci. 78:185-194.

Bishop, S. C., and C. A. Morris. 2007. Genetics of disease resistance in sheep and goats. Small Rumin. Res. 70:48-59.

Bishop, S. C., and M. J. Stear. 2001. Inheritance of faecal egg counts during early lactation in Scottish Blackface ewes facing mixed, natural nematode infections. Anim. Sci. 73:389-395.

Bishop, S. C., and M. J. Stear. 2003. Modeling of host genetics and resistance to infectious diseases: Understanding and controlling nematode infections. Vet. Parasitol. 115:147-166.

Boyazoglu, J., and P. Morand-Fehr. 2001. Mediterranean dairy sheep and goat products and their quality. A critical review. Small Rumin. Res. 40:1-11.

Bruce, M. E., R. G. Will, J. W. Ironside, L. McConnel, D. Drummond, A. Suttie, L. McCardle, A. Chree, J. Hope, C. Birkett, S. Cousens, H. Fraser, and C. J. Bostock. 1997. Transmissions to mice indicate that "new variant" CJD is caused by the same BSE agent. Nature 389:498-501.

Buckrell, B. C., C. Buschbeck, C. J. Gartley, T. Kroetsch, W McCutcheon, J. Martin, W. K. Penner, and J. S. Walton. 1994. Further development of a transcervical technique for artificial insemination in sheep using previously frozen semen. Theriogenology 42:601-611.

Cabiddu, A., M. Decandia, M. Addis, G. Piredda, A. Pirisi, and G. Molle. 2005. Managing Mediterranean pastures in order to enhance the level of beneficial fatty acids in sheep milk. Small Rumin. Res. 59:169-180.

Caja, G., and M. de Rancourt. 2002. Situation actuelle et perspectives de la production des ovins laitiers en Espagne. Options Méditerranéennes . Sèrie B. 39:57-66. 
Carriedo, J. A., J. A. Baro, L. F. de la Fuente, and F. San Primitivo 1995. Genetic parameters for milk yield in dairy sheep. J. Anim. Breed. Genet. 112:58-63.

Carta, A., F. Barillet, D. Allain, Y. Amigues, B. Bibe, L. Bodin, S. Casu, E. Cribiu, J. M. Elsen, A. Fraghi, L. Gruner, P. Jacquiet, S. Ligios, C. Marie-Etancelin, L. Mura, G. Piredda, R. Rupp, S. R. Sanna, A. Scala, L. Schibler, and S. Casu. 2002. QTL detection with genetic markers in a dairy sheep backcross Sarda $\times$ Lacaune population. In Proc. 7th World Congr. Genet. Appl. Livest. Prod. CD-ROM. Commun. no. 01-40. INRA, Castanet-Tolosan, France.

Carta, A., S. Casu, M. G. Usai, M. Addis, M. Fiori, A. Fraghì, S. Miari, L. Mura, G. Piredda, L. Schibler, T. Sechi, J. M. Elsen, and F. Barillet. 2008. Investigating the genetic component of fatty acid content in sheep milk. Small Rumin. Res. 79:22-28.

Carta, A., M. De Candia, N. Fois, A. Ledda, C. Ligios, S. Ligios, G. Molle, S. R. Sanna, A. Scala, and S. Casu. 2004. Datasheet on Sardinian sheep. In Animal Health and Production Compendium. CD-ROM. CAB International, Wallingford, UK.

Carta, A., S. R. Sanna, and S. Casu. 1995. Estimating lactation curves and seasonal effects for milk, fat and protein in Sarda dairy sheep with a test day model. Livest. Prod. Sci. 44:37-44.

Carta, A., S. R. Sanna, and S. Casu. 1998b. The use of equivalent mature ewe for the genetic evaluation of Sarda dairy sheep. Pages 173-176 in Proc. 6th World Congr. Genet. Appl. Livest. Prod. Armidale, Australia. (XXIV). Organizing committee, Armidale, Australia.

Carta, A., S. R. Sanna, A. Rosati, and S. Casu. 1998a. Milk yield adjustments for milking length and age-parity-month of lambing interaction in Sarda dairy sheep. Ann. Zootech. 47:59-66.

Carta, A., T. Sechi, M. G. Usai, M. Addis, M. Fiori, A. Fraghì, S. Miari, L. Mura, G. Piredda, J. M. Elsen, L. Schibler, F. Barillet, and S. Casu. 2006. Evidence for a QTL affecting the synthesis of conjugated linoleic acid cis-9, trans-11 from trans-11-C:18:1 acid on ovine chromosome 22. In Proc 8th World Congr. Genet. Appl. Livest. Prod. Belo Horizonte, Brazil. CD Commun. No 12-03. Organizing committee, Belo Horizonte, MG, Brazil.

Casu, S., S. Deiana, S. Tolu, and A. Carta. 2000. Linear evaluation of udder morphology in Sarda dairy sheep: Relationship with milk yield. Pages 195-198 in Proc. XIV Nat. Congr. SIPAOC, 1.

Casu, S., C. Marie-Etancelin, L. Schibler, E. Cribiu, L. Mura, T. Sechi, A. Fraghì, A. Carta, and F. Barillet. 2003. A genome scan to identify quantitative trait loci affecting udder morphology traits in dairy sheep. In Proc. International Workshop on Major Genes and QTL in Sheep and Goat. Com. no. 2-19. INRA-SAGA, CastanetTolosan, France.

Casu, S., I. Pernazza, and A. Carta. 2006. Feasibility of a linear scoring method of udder morphology for the selection scheme of Sardinian sheep. J. Dairy Sci. 89:2200-2209.

Casu, S., C. Marie-Etancelin, C. Robert-Granié, F. Barillet, and A. Carta. 2007. Evolution during the productive life and individual variability of milk emission at machine milking in Sardinian $x$ Lacaune back-cross ewes. Small Rumin. Res. 75:7-16.

Cazeau, G., A. Fediaevsky, and D. Calavas. 2008. Prevalence of classical and atypical scrapie in sheep and goats in France between 2002 and 2006. Rev. Med. Vet. 159:348-356.

Chilliard, Y., A. Ferlay, R. M. Mansbridge, and M. Doreau. 2000 Ruminant milk fat plasticity: Nutritional control of saturated, polyunsaturated, trans and conjugated fatty acids. Ann. Zootech. 49:181-205.

Costard, A. D., Z. G. Vitezica, C. R. Moreno, and J. M. Elsen. 2009. A dynamic deterministic model to optimize a multiple-trait selection scheme. J. Anim. Sci. 87:885-894.

Crawford, A. M., K. G. Dodds, A. J. Ede, C. A. Pierson, G. W Montgomery, H. G. Garmonsway, A. E. Beattie, K. Davies, J. F. Maddox, and S. W. Kappes. 1995. An autosomal genetic linkage map of the sheep genome. Genetics 140:703-724.

Cringoli, G., V. Veneziano, F. Jackson, J. Vercuysse, A. W. Greer, V. Fedele, L. Mezzino, and L. Rinaldi. 2008. Effects of strategic anthelmintic treatments on the milk production of dairy sheep naturally infected with gastrointestinal strongyles. Vet. Parasitol. 156:340-345
David, I., J. M. Astruc, G. Lagriffoul, E. Manfredi, C. Robert-Granie, and L. Bodin. 2008. Genetic correlation between female fertility and milk yield in Lacaune Sheep. J. Dairy Sci. 91:4047-4052.

Davies, G., M. J. Stear, and S. C. Bishop. 2005. Genetic relationships between indicator traits and nematode parasite infection levels in 6 month old lambs. Anim. Sci. 80:143-150.

Dawson, M., R. C. Moore, and S. C. Bishop. 2008. Progress and limits of $\operatorname{PrP}$ gene selection policy. Vet. Res. 39:25.

de Heredia, I. B., E. Ugarte, B. Malpaux, S. Canepa, and L. Bodin. 2002. Genetic aspects of out of season breeding ability of Latxa breed. Proc. 7th World Congr. Genet. Appl. Livest. Prod. Montepellier, France. CD commun. No 08-22. INRA, CastanetTolosan, France.

de la Fuente, L. F., G. Fernandez, and F. San Primitivo. 1996. A linear evaluation system for udder traits of dairy ewes. Livest. Prod. Sci. $45: 171-178$

De Rancourt, M., N. Fois, M. P. Lavín, E. Tchakérian, and F. Vallerand. 2006. Mediterranean sheep and goats production: An uncertain future. Small Rumin. Res. 62:167-179.

De Vries, F. H. Hamman, C. Drögemüller, M. Ganter, and O. Distl. 2005. Analysis of associations between the prion protein genotypes and production traits in East Friesian milk sheep. J. Dairy Sci. 88:392-398

Dekkers, J. C. M. 2004. Commercial application of marker- and geneassisted selection in livestock: Strategies and lessons. J. Anim. Sci. 82(E-Suppl.):E313-E328.

Demeyer, D., and M. Doreau. 1999. Pourquoi et comment modifier les lipides du lait et de la viande bovine. Cahiers Nutr. Diet. 34:301-308

Diez-Tascón, C., Y. Bayon, J. J. Arranz, L. F. de la Fuente, and F. San Primitivo. 2001. Mapping quantitative trait loci for milk production traits on ovine chromosome 6. J. Dairy Res. 68:389 397.

Drögemüller, C., T. Leeb, and O. Distl. 2001. PrP genotype frequencies in German breeding sheep and the potential to breed for resistance to scrapie. Vet. Rec. 149:349-352.

Eady, S. J., R. R. Woolaston, and I. A. Barger. 2003. Comparison of genetic and non genetic strategies for control of gastrointestinal nematodes of sheep. Livest. Prod. Sci. 81:11-23.

EFSA. 2006. Opinion of the Scientific Panel on Biological Hazards on "the breeding programme for TSE resistance in sheep". The EFSA Journal 382:1-46.

El Saied, U. M., J. A. Carriero, L. F. de la Fuente, and F. San Primitivo. 1999. Genetic parameters of lactation cell counts and milk and protein yield in dairy ewes. J. Dairy Sci. 81:2956-2961.

El Saied, U. M., J. A. Carriero, and F. San Primitivo. 1998. Heritability of test day somatic cell counts and its relationship with milk yield and protein percentage in dairy ewes. J. Dairy Sci. 81:29562961.

El Zarei, M. F., J. J. Arranz, B. Gutierrez-Gil, Y. Bayon, L. F. de la Fuente, and F. San Primitivo. 2002. Scanning chromosome 9 for QTL underlying milk production traits in Spanish Churra breed. Proc. 7th World Congr. Genet. Appl. Livest. Prod. Montepellier, France. CD Commun. No 01-81. INRA, Castanet-Tolosan, France.

Elsen, J. M., Y. Amigues, F. Schelcher, V. Ducrocq, O. Andreoletti, F. Eychenne, J. V. Tien Khang, J. P. Poivey, F. Lantier, and J. L. Laplanche. 1999. Genetic susceptibility and transmission factors in scrapie: Detailed analysis of an epidemic in a closed flock of Romanov. Arch. Virol. 144:431-445.

Elsen, J. M., and J. C. Mocquot. 1974. Recherches pour une rationalisation technique et économique des schémas de sélection des bovins et ovins. Pages 76-97 in Bulletin Technique du Département de Génétique Animale. INRA, Jouy-en-Josas, France.

Elsen, J. M., C. R. Moreno, L. Bodin, D. François, J. Bouix, F Barillet, D. Allain, F. Lantier, I. Lantier, L. Schibler, A. Roig, J. C. Brunel, and Z. G. Vitezica. 2006. Selection for Scrapie resistance in France: Is there evidence of negative effects on production and health traits? Proc. 8th World Congr. Genet. Appl. Livest. Prod., Belo Horizonte, Minas Gerais, Brazil. CD Commun. No 15-15. Organizing committee, Belo Horizonte, MG, Brazil. 
Epstein, H. 1985. The Awassi sheep with special reference to the improved dairy type. Animal Production and Health Paper No. 57. FAO, Rome, Italy.

European Commission. 2003. 2003/100/EC Commission decision laying down minimum requirements for the establishment of breeding programs for resistance to transmissible spongiform encephalopathies in sheep. Off. J. L 041:41-45.

FAOSTAT. 2009. http://faostat.fao.org/site/573/default.aspx\#ancor Accessed Apr. 27, 2009.

Fernandez, G., J. A. Baro, L. F. de la Fuente, and F. San Primitivo. 1997. Genetic parameters for linear udder of dairy ewes. J. Dairy Sci. 80:601-605.

Finocchiaro, R., J. B. C. H. M. van Kaam, B. Portolano, and I. Misztal. 2005. Effect of heat stress on production of Mediterranean dairy sheep. J. Dairy Sci. 88:1855-1864.

Fthenakis, G. C., E. Papadopoulos, and C. Himonas. 2005. Effects of three anthelmintic regimes on milk yield of ewes and growth of lamb. J. Vet. Med. A Physiol. Pathol. Clin. Med. 52:78-82.

Galal, E. S. E. 1994. Strategies for the genetic improvement of fat-tail sheep in the Near East. Pages 5-9 in Strategies For the Development of Fat-Tail Sheep in the Near East. EAAP Publication No 68EAAP, Wageningen, the Netherlands.

Galal, S., O. Gürsoy, and I. Shaat. 2008. Awassi sheep as a genetic resource and efforts for their genetic improvement-A review. Small Rumin. Res. 79:79-108.

Gonzalez-Recio, O., R. Alenda, Y. M. Chang, K. Weigel, and D. Gianola. 2006. Selection for female fertility using censored fertility traits and investigation of the relationship with milk production. J. Dairy Sci. 89:4438-4444.

Griinari, J. M., and D. E. Bauman. 1999. Biosynthesis of conjugated linoleic acid and its incorporation into meat and milk in ruminants. Pages 180-200 in Advances in Conjugated linoleic Acid Research. Vol. 1. M. P. Yurawecz, M. M. Mossoba, J. K. G. Kramer, M. W. Pariza, and G. J. Nelson, ed. AOCS Press, Champaign, IL.

Gruner, L., J. Bouix, and J. C. Brunel. 2004a. High genetic correlation between resistance to Haemonchus contortus and to Trichostrongylus colubriformis in INRA 401 sheep. Vet. Parasitol. 119:51-58.

Gruner, L., J. Bouix, J. Vu Tien Khang, N. Mandonnet, F. Eychenne, J. Cortet, C. Sauvé, and C. Limouzin. 2004b. A short-term divergent selection for resistance to Teladorsagia cirumcinta in Romanov sheep using natural or artificial challenge. Genet. Sel. Evol. 36:217-242.

Gutiérrez, J. P., E. Legaz, and F. Goyache. 2007. Genetic parameters affecting 180-days standardised milk yield, test-day milk yield and lactation length in Spanish Assaf (Assaf.E) dairy sheep. Small Rumin. Res. 70:233-238.

Gutiérrez-Gil, B., M. F. El-Zarei, L. Alvarez, Y. Bayón, L. F. de la Fuente, F. San Primitivo, and J. J. Arranz. 2008. Quantitative trait loci underlying udder morphology traits in dairy sheep. J. Dairy Sci. 91:3672-3681.

Gutiérrez-Gil, B., M. F. El-Zarei, L. Alvarez, Y. Bayon, L. F. de la Fuente, F. Primitivo, and J. Arranz. 2009. Quantitative trait loci underlying milk production traits in sheep. Animal Genetics 40:423-434.

Gutiérrez-Gil, B., M. F. El-Zarei, Y. Bayón, L. Álvarez, L. F. de la Fuente, F. San Primitivo, and J. J. Arranz. 2007. Short communication: Detection of quantitative trait loci influencing somatic cell score in Spanish Churra sheep. J. Dairy Sci. 90:422426.

Haenlein, G. F. W. 2007. About the evolution of goat and sheep milk production. Small Rumin. Res. 68:3-6.

Hanocq, E., L. Bodin, J. Thimonier, J. Teyssier, B. Mcalpaux, and P. Chemineau. 1999. Genetic parameters of spontaneous spring ovulatory activity in Mérinos d'Arles sheep. Genet. Sel. Evol. 31:77-90.

Harfoot, C. G., and G. P. Hazlewood. 1997. Lipid metabolism in the rumen. Pages 285-322 in The Rumen Microbial Ecosystem. P. N. Hobson, ed. Elsevier Applied Science Publishers, London, UK.

Hayes, K. C., and D. R. Khosla. 1992. Dietary fatty acid thresholds and cholesterolemia. FASEB J. 6:2600-2607.
Hoste, H., and C. Chartier. 1993. Comparison of the effects on milk production of concurrent infection with Haemonchus contortus and Trichostrongylus colubriformis in high- and low-producing dairy goats. Am. J. Vet. Res. 54:1886-1893.

ICAR. 1992. International Regulations for Milk Recording in Sheep. Institut de l'Elevage, Paris, France.

ICAR. 2007. International Agreement of Recording Practices. Guidelines approved by the General Assembly held in Kuopio, Finland on June 2006. Section 2.2: 55-65.International Committee of Animal Recording, Rome, Italy.

Ioannides, I. M., A. P. Mavrogenis, and C. Papachristoforou. 2009 Analysis of $\mathrm{PrP}$ genotypes in relation to reproductive and production traits in Chios sheep. Livest. Sci. 122:296-301.

Jordan, J. R. A., and G. A. L. Pérez. 1991. Effect of treatment with netobimin on milk production of sheep. Vet. Parasitol. 38:173183.

Jurado, J. J., M. Serrano, and M. D. Pérerz Guzmán. 2006. Análisis del progreso genético obtenido en el esquema de selection de la raza ovina Manchega. ITEA J. 102:41-54.

Kaplan, R. M. 2004. Drug resistance in nematodes of veterinary importance: A status report. Trends Parasitol. 20:477-481.

Konold, T., S. J. Moore, S. J. Bellworthy, and H. A. Simmons. 2008. Evidence of scrapie transmission via milk. BMC Vet. Res. 4:14.

Kramer, J. K. G., P. W. Parodi, R. G. Jensen, M. M. Mossoba, M. P. Yurawecz, and R. O. Adlof. 1998. Rumenic acid: A proposed common name for the major conjugated linoleic acid isomer found in natural products. Lipids 33:835.

Labussière, J. 1988. Review of physiological and anatomical factors influencing the milking ability of ewes and the organisation of milking. Livest. Prod. Sci. 18:253-274.

Lacroux, C., S. Simon, S. L. Benestad, S. Maillet, J. Mathey, S. Lugan, F. Corbière, H. Cassard, P. Costes, D. Bergonier, J. L. Weisbecker, T. Moldal, H. Simmons, F. Lantier, C. Feraudet-Tarisse, N. Morel, F. Schelcher, J. Grassi, and O. Andréoletti. 2008. Prions in milk from ewes incubating natural scrapie. PLoS Pathog. 4:e1000238 doi:10.1371/journal.ppat.1000238

Legarra, A., P. López-Romero, and E. Ugarte. 2005. Bayesian model selection of contemporary groups for BLUP genetic evaluation in Latxa dairy sheep. Livest. Prod. Sci. 93:205-212.

Legarra, A., and E. Ugarte. 2001. Genetic parameters of milk traits in Latxa dairy sheep. Anim. Sci. 73:407-412.

Legarra, A., and E. Ugarte. 2005. Genetic parameters of udder traits, somatic cell score, and milk yield in Latxa sheep. J. Dairy Sci. 88:2238-2245.

Legarra, A., E. Ugarte, and F. Arrese. 2003. Analysis of the genetic progress in the Latxa breed breeding program. Informació TécnicoEconómica Agraria 99A:192-202.

Legarra, A., E. Ugarte, and I. Beltran de Heredia. 2004. Analisis de asociaciòn y producciòn de leche en raza Latxa. ITEA 100A:127133.

Ligios, C., C. J. Sigurdson, C. Santucciu, G. Carcassola, G. Manco, M. Basagni, C. Maestrale, M. G. Cancedda, L. Madau, and A. Aguzzi. 2005. PrPSc in mammary glands of sheep affected by scrapie and mastitis. Nat. Med. 11:1137-1138.

Luna, P., J. Fontecha, M. Juárez, and M. A. de la Fuente. 2005. Conjugated linoleic acid in ewe milk fat. J. Dairy Res. 72:415424.

Macciotta, N. P. P., M. Mele, A. Cappio-Borlino, and P. Secchiari. 2005. Issues and perspectives in dairy sheep breeding. Ital. J. Anim. Sci. 4:5-23.

Maddox, J. F., and N. E. Cockett. 2007. An update on sheep and goat linkage maps and other genomic resources. Small Rumin. Res. 70:4-20.

Maestrale, C., A. Galistu, F. Demontis, A. Carta, M. Saba, M. G. Cancedda, R. Zucca, P. Uras, and C. Ligios. 2005. Effect of QQ171 genotype frequency on Scrapie prevalence in Sarda sheep flocks. Page 294 in Proceedings of Prions 2005: Between Fundamentals and Society's Needs. Neuroprion, Munich, Germany.

Marcotegui, N., A. Parada, L. Alfonso, and A. Arana. 2003. PrP genotyping in a flock of Assaf sheep: Polymorphism and relation with milk yield. Page 329 in Book of Abstracts of the 54th Annual 
Meeting of the European Association for Animal Production No 9. Rome, Italy. Wageningen Academic Publishers, Wageningen, the Netherlands.

Maria, G., and D. Gabina. 1992. Simplification of milk recording scheme in Latxa milk sheep. Livest. Prod. Sci. 31:313-320.

Marie-Etancelin, C., J. M. Astruc, D. Porte, H. Larroque, and C Robert-Granie. 2005. Multiple-trait genetic parameters and genetic evaluation of udder-type traits in Lacaune dairy ewes. Livest. Prod. Sci. 97:211-218.

Marie-Etancelin, C., E. Manfredi, M. R. Aurel, F. Pailler, J. Arhainx, E. Ricard, G. Lagriffoul, P. Guillouet, B. Bibe, and F. Barillet. 2006. Genetic analysis of milking ability in Lacaune dairy ewes. Genet. Sel. Evol. 38:183-200.

Marie-Etancelin, C., S. Casu, M. R. Aurel, F. Barillet, A. Carta, S. Deiana, M. Jacquin, F. Pailler, D. Porte, and S. Tolu. 2003. New tools to appraise udder morphology and milkability in dairy sheep. Options Médit. A 55:71-80.

Mavrogenis, A. P., A. Koumas, and G. Gavrielidis. 1999. The inheritance of somatic cell counts in Chios sheep. Pages 389-392 in Proc. of the Sixth International Symposium on Milking of Small Ruminants, vol. 95, Athens, Greece. EAAP, Wageningen, the Netherlands.

Mele, M., R. Dal Zotto, M. Cassandro, G. Conte, A. Serra, A. Buccioni, G. Bittante, and P. Secchiari. 2009. Genetic parameters for conjugated linoleic acid, selected milk fatty acids, and milk fatty acid unsaturation of Italian Holstein-Friesian cows. J. Dairy Sci. 92:392-400.

Meuwissen, T. H. E., B. Hayes, and M. E. Goddard. 2001. Prediction of total genetic value using genome-wide dense marker maps. Genetics 157:1819-1829.

Miari, S., M. G. Usai, T. Sechi, A. Pernisa, and A. Carta. 2009. One polymorphism at the stearoyl CoA desaturase (SCD) gene is associated to CLA content of sheep milk fat. Ital. J. Anim. Sci. $8: 108-110$.

Moioli, B., M. D'Andrea, and F. Pilla. 2007. Candidate genes affecting sheep and goat milk quality. Small Rumin. Res. 68:179-192.

Moreno, C. R., G. M. Cosseddu, L. Schibler, A. Roig, K. MoazamiGoudarzi, O. Andreoletti, F. Eychenne, D. Lajous, F. Schelcher, E. P. Cribiu, P. Laurent, D. Vaiman, and J. M. Elsen. 2008. Identification of new quantitative trait loci (other than the PRNP gene) modulating the scrapie incubation period in sheep. Genetics 179:723-726.

Moreno, C. R., L. Gruner, A. Scala, L. Mura, L. Schibler, Y. Amigues, T. Sechi, P. Jacquiet, D. François, S. Sechi, A. Roig, S. Casu, F. Barillet, J. C. Brunel, J. Bouix, A. Carta, and R. Rupp. 2006. QTL for resistance to internal parasites in two designs based on natural and experimental conditions of infection. In Proc. 8th World Congr. Genet. Appl. Livest. Prod., Belo Horizonte, Minas Gerais, Brazil. CD Commun. No. 15-05. Organizing committee, Belo Horizonte, MG, Brazil.

Morris, C. A., S. A. Bisset, A. Vlassoff, C. J. West, and M. Wheeler. 1998. Faecal nematode egg counts in lactating ewes from Romney flocks selectively bred for divergence in lamb faecal egg count. Anim. Sci. 67:283-288.

Morris, C. A., A. Vlassoff, S. A. Bisset, R. L. Baker, C. J. West, and A. P. Hurford. 1997. Responses of Romney sheep to selection for resistance or susceptibility to nematode infection. Anim. Sci. 64:319-329.

Mrode, R. A., and G. J. T. Swanson. 1996. Genetic and statistical properties of somatic cell count and its suitability as an indirect means of reducing the incidence of mastitis in dairy cattle. Anim. Breed. Abstr. 64:847-857.

Moussaoui, Y., G. Caja, J. Casellas, X. Such, and O. Francino. 2005. Asociaciónes entre genotipo PrP y caracteres productivos en ovino lechero de raza Manchega y Lacaune: Primeros resultados en prolificidad y peso al nacimiento. http://acteon.webs.upv.es/ CONGRESOS/AIDA\%202005/Trabajos.htm Accessed Oct. 2, 2009 .

Othmane, M. H., J. A. Carriedo, F. San Primitivo, and L. F. de la Fuente. 2002. Genetic parameters for lactation traits of milking ewes: Protein content and composition, fat, somatic cells and individual laboratory cheese yield. Genet. Sel. Evol. 34:581-596.

Palhière, I., M. Brochard, K. Moazami-Goudarzi, D. Laloë, Y. Amigues, B. Bed'hom, É. Neuts, C. Leymarie, T. Pantano, E. P Cribiu, B. Bibé, and É. Verrier. 2008. Impact of strong selection for the $\mathrm{PrP}$ major gene on genetic variability of four French sheep breeds. Genet. Sel. Evol. 40:663-680.

Papadopoulos, E. M. 2008. Anthelmintic resistance in sheep nematodes. Small Rumin. Res. 76:99-106.

Pascal, G. 1996. Les apports quotidiens recommandés en lipides et en acides gras. OCL 3:205-210.

Pirisi, A., A. Lauret, and J. P. Dubeuf. 2007. Basic and incentive payments for goat and sheep milk in relation to quality. Small Rumin. Res. 68:167-178.

Pirisi, A., G. Piredda, C. M. Papoff, R. Di Salvo, S. Pintus, G. Garro, P. Ferranti, and L. Chianese. 1999. Effects of sheep os1-casein CC, $\mathrm{CD}$ and DD genotypes on milk composition and cheesemaking properties . J. Dairy Res. 66:409-419.

Pollott, G. E., and E. Gootwine. 2004. Reproductive performance and milk production of Assaf sheep in an intensive management system. J. Dairy Sci. 87:3690-3703.

Portolano, B., R. Finocchiaro, and J. B. C. H. M. van Kaam. 2006. Comparison of selection criteria for milk yield traits of Valle del Belice dairy sheep. Livest. Sci. 99:277-284.

Ricordeau, G., and J. C. Flamant. 1969. Croisements entre les races ovines Préalpes du Sud et Frisonne (Ostfriesisches Milchschaf). II Reproduction, viabilité, croissance, conformation. Ann. Zootech. 18:131-149.

Riggio, V., R. Finocchiaro, J. B. C. H. M. van Kaam, B. Portolano, and H. Bovenhuis. 2007. Parameters for milk somatic cell score and relationships with production traits in primiparous dairy sheep. J. Dairy Sci. 90:1998-2003.

Rupp, R., D. Bergonier, S. Dion, M. C. Hygonenq, M. R. Aurel, C. Robert-Granié, and G. Foucras. 2009. Response to somatic cell count-based selection for mastitis resistance in a divergent selection experiment in sheep. J. Dairy Sci. 92:1203-1219.

Rupp, R., and D. Boichard. 2003. Genetics of resistance to mastitis in dairy cattle. Vet. Res. 34:671-688.

Rupp, R., D. Boichard, A. Barbat, J. Astruc, G. Lagriffoul, and F. Barillet. 2002. Selection for mastitis resistance in French dairy sheep. Pages 119-122 in Proc. 7th Congr. Genet. Appl. Livest. Prod. 31. INRA, Castanet-Tolosan, France.

Rupp, R., G. Lagriffoul, J. M. Astruc, and F. Barillet. 2003a. Genetic parameters for milk somatic cell scores and relationships with production traits in French Lacaune dairy sheep. J. Dairy Sci. $86: 1476-1481$

Rupp, R., L. Schibler, E. Cribiu, Y. Amigues, M. Y. Boscher, L. Mura, T. Sechi, A. Fraghi, S. Casu, F. Barillet, and A. Carta. 2003b. Evidence of chromosomal regions controlling somatic cell counts in dairy sheep from two QTL detection project. In Proc. International Workshop on Major Genes and QTL in Sheep and Goat. INRASAGA, Castanet-Tolosan, France. CD-ROM. Commun. no. 2-32.

Salaris, S., S. Casu, and A. Carta. 2007. Investigating the relationship between the prion protein locus and udder morphology traits and milk yield in Sardinian sheep. J. Anim. Sci. 85:2840-2845.

Salaris, S., S. Casu, P. Fresi, and A. Carta. 2008. Effect of combining controlled natural mating with artificial insemination on the genetic structure of the flock book of Sardinian breed sheep. Pages 113-122 in Proc. 36th Biennial Session of the International Committee for Animal Recording (ICAR), Niagara Falls, NY. ICAR technical series no. 13. Identification, breeding, production, health and recording on farm animals. J. D. Slatter, ed. ICAR, Rome, Italy.

Salaris, S., L. Crasta, P. Fozzi, A. Fraghì, S. Casu, S. R. Sanna, and A. Carta. 2004. Selezione per la resistenza alla scrapie nella razza sarda: Relazioni con la produzione di latte. Page 199 in Proc. XVI Nat. Congr. SIPAOC, Siena, Italy.

Sanna, S. R., A. Carta, P. Cappai, A. Branca, G. Festante, and P. L. Bitti. 1997a. Environmental effects on fertility of artificially inseminated Sarda dairy ewes. Proc. 48th Annual Meeting of the EAAP, Vienna, Austria. Abstr: S5.5. Wageningen Pers, Wageningen, the Netherlands. 
Sanna, S. R., A. Carta, and S. Casu. 1997b. (Co)variance component estimates for milk composition traits in Sarda dairy sheep using a bivariate animal model. Small Rumin. Res. 25:77-82.

Sanna, S. R., A. Carta, and S. Casu. 2002. Genotype by environment interaction for milk yield in Sarda dairy sheep. J. Anim. Breed. Genet. 119:190-199.

Sanna, S. R., A. Carta, S. Casu, B. M. Moioli, and A. M. Pilla. 1994. Valutazione genetica della razza ovina Sarda. II. Ereditabilità e correlazioni genetiche. Zoot. Nutr. Anim. 20:247-251.

Sanna, S. R., S. Casu, G. Ruda, A. Carta, S. Ligios, and G. Molle. 2001. Comparison between native and 'synthetic' sheep breeds for milk production in Sardinia. Livest. Prod. Sci. 71:11-16.

Scala, A., L. Ermini, P. P. Mula, M. Giobbe, A. P. Pipia, S. Tolu, S. Casu, and A. Carta. 2008. Influenza di un trattamento antielmintico sulle produzioni quali-quantitative di latte in ovini primipari con infestione naturale da Nematodi gastro-intestinali. Large Anim. Rev.(Suppl.):4-14, 224

Scatà, M. C., F. Napolitano, S. Casu, A. Carta, G. De Matteis, F. Signorelli, G. Annicchiarico, G. Catillo, and B. Moioli. 2009. Ovine acyl CoA:diacylglycerol acyltransferase 1 (DGAT1): Molecular characterization, polymorphisms and association with milk traits. Anim. Genet. 40:737-742.

Sechi, S., S. Salaris, A. Carta, and S. Casu. 2007. Relationships between SCC and udder morphology traits in Sardinian sheep. Page 68 in Proc. 5th International Symposium on the Challenge to Sheep and Goats Milk Sectors, Alghero, Italy.

Sechi, S., S. Salaris, A. Scala, R. Rupp, C. Moreno, S. C. Bishop, and S. Casu. 2009. Estimation of (co)variance components of nematode parasites resistance and somatic cell count in dairy sheep. Ital. J. Anim. Sci. 8:156-158.

Serrano, M., M. D. Pérez-Guzmán, V. Montoro, and J. J. Jurado. 1996. Genetic parameters estimation and selection progress for milk yield in Manchega sheep. Small Rumin. Res. 23:51-57.

Serrano, M., M. D. Pérez-Guzmán, V. Montoro, and J. J. Jurado. 2002. Genetic analysis of udder traits in Manchega ewes. Livest. Prod. Sci. 77:355-361.

Serrano, M., M. D. Pérez-Guzmán, V. Montoro, and J. J. Jurado. 2003. Genetic analysis of somatic cell count and milk traits in Manchega ewes. Mean lactation and test-day approaches. Livest. Prod. Sci. 84:1-10.

Serrano, M., E. Ugarte, J. J. Jurado, M. D. Pérez-Guzmán, and A. Legarra. 2001. Test day models and genetic parameters in Latxa and Manchega dairy ewes. Livest. Prod. Sci. 67:253-264.

Smulders, J. P., M. Serrano, M. D. Pérez-Guzmán, M. A. Jimenez, H. Uribe, and J. J. Jurado. 2007. Stochastic simulation of Manchega sheep breed selection scheme. Impact of artificial insemination, progeny testing system and nucleus size on genetic progress and inbreeding. Livest. Sci. 106:218-231.
Soyeurt, H., P. Dardenne, F. Dehareng, G. Lognay, D. Veselko, M. Marlier, C. Bertozzi, P. Mayeres, and N. Gengler. 2006b. Estimating fatty acid content in cow milk using mid-infrared spectrometry. J. Dairy Sci. 89:3690-3695.

Soyeurt, H., P. Dardenne, A. Gillon, C. Croquet, S. Vanderick, P. Mayeres, C. Bertozzi, and N. Gengler. 2006a. Variation in fatty acid contents of milk and milk fat within and across breeds. J. Dairy Sci. 89:4858-4865.

Soyeurt, H., A. Gillon, S. Vanderick, P. Mayeres, C. Bertozzi, and N. Gengler. 2007. Estimation of heritability and genetic correlations for the major fatty acids in bovine milk. J. Dairy Sci. 90:44354442.

Stear, M. J., K. Bairden, J. L. Duncan, P. H. Holmes, Q. A. McKellar, M. Park, S. Strain, M. Murray, S. C. Bishop, and G. Gettinby. 1997. How hosts control worms. Nature 389:27.

Ugarte, E., R. Ruiz, D. Gabiña, and I. Beltrán de Heredia. 2001. Impact of high-yielding foreign breeds on the Spanish dairy sheep industry. Livest. Prod. Sci. 71:3-10.

Van Kaam, J. B. C. H. M., R. Finocchiaro, D. O. Maizon, M. Vitale, F. Vitale, S. Caracappa, and B. Portolano. 2006. Effect of the PrP gene on milk production in Valle del Belice. Proc 8th World Congr. Genet. Appl. Livest. Prod., Belo Horizonte, Minas Gerais, Brazil. CD Commun. No. 02-12.

Veerkamp, R. F., B. Beerda, and T. van der Lende. 2003. Effects of genetic selection for milk yield on energy balance, levels of hormones, and metabolites in lactating cattle, and possible links to reduced fertility. Livest. Prod. Sci. 83:257-275.

Wall, E., S. Brotherstone, J. A. Woolliams, G. Banos, and M. P. Coffey. 2003. Genetic evaluation of fertility using direct and correlated traits. J. Dairy Sci. 86:4093-4102.

Woolaston, R. R. 1992. Selection of Merino sheep for increased and decreased resistance to Haemonchus contortus: Peri-parturient effects on faecal egg counts. Int. J. Parasitol. 22:947-953.

Woolaston, R. R., I. A. Barger, and L. R. Piper. 1990. Response to helminthes infection of sheep selected for resistance to Haemonchus contortus. Int. J. Parasitol. 20:1015-1018.

Woolaston, R. R., and L. R. Piper. 1996. Selection of merino sheep for resistance to Haemonchus contortus: Genetic variation. Anim. Sci. 62:451-460.

Woolaston, R. R., and R. G. Windon. 2001. Selection of sheep for response to Trichostrongylus colubriformis larvae: Genetic parameters. Anim. Sci. 73:41-48.

Zervas, N., J. Boyazoglu, P. Kalaissakis, T. Papadimitiou, and J. Flamant. 1975. Comparaison des races ovines Chios et Frisonne avec leurs croisements en Grèce continentale. I. Viabilité et reproduction. Ann. Genet. Sel. Anim. 7:277-291.

Zygoyiannis, D. 2006. Sheep production in the world and in Greece. Small Rumin. Res. 62:143-147. 